\title{
South American Monsoon variability over the last millennium in paleoclimate records and isotope-enabled climate models
}

Rebecca Orrison ${ }^{1}$, Mathias Vuille ${ }^{1}$, Jason E. Smerdon ${ }^{2}$, James Apaéstegui ${ }^{3,4}$, Jose Leandro P. S. Campos $^{5}$, Francisco W. Cruz ${ }^{5}$, Marcela Eduarda Della Libera ${ }^{5,6}$

5

${ }^{1}$ Department of Atmospheric and Environmental Sciences, University at Albany, Albany, NY, 12226, USA

${ }^{2}$ Lamont-Doherty Earth Observatory, Columbia University, Palisades, New York, 10964, USA

${ }^{3}$ Peruvian Institute of Geophysics, Lima, 15012, Peru

${ }^{4}$ Universidad Nacional Agraria La Molina, Lima, 15024, Perú

10 Institute of Geosciences, University of São Paulo, São Paulo, 05508, Brazil

${ }^{6}$ Institute for Geosciences, Johannes-Gutenberg-Universität, Mainz, Rhineland-Palatinate, 55122, Germany

Correspondence to: Rebecca Orrison (rorrison@albany.edu)

Abstract. The South American Monsoon System (SAMS) is the main driver of regional hydroclimate variability across tropical and subtropical South America. It is best recorded on paleoclimatic timescales by stable oxygen isotope proxies,

15 which are more spatially representative of regional hydroclimate than proxies for local precipitation alone. Network studies of proxies that can isolate regional influences lend particular insight into various environmental characteristics that modulate hydroclimate, such as atmospheric circulation variability and changes in the regional energy budget as well as understanding the climate system sensitivity to external forcings. To extract the coherent modes of variability of the SAMS over the Last Millennium (LM), we use a Monte Carlo Empirical Orthogonal Function (MCEOF) decomposition of $14 \delta^{18} \mathrm{O}$ proxy records and compare them with modes extracted from a similar decomposition using isotope-enabled climate models. The two leading modes reflect the isotopic expression of the upper-tropospheric monsoon circulation (Bolivian High - Nordeste Low waveguide) and the latitudinal displacement of the South Atlantic Convergence Zone (SACZ), respectively. The spatial characteristics of these modes appear to be robust features of the LM hydroclimate over South America and are reproduced both in the proxy data and in isotope-enabled climate models, regardless of the nature of the model-imposed external forcing.

25 Model analyses suggests that the local isotopic composition is primarily a reflection of an upstream rainout processes. The proxy data document that the SAMS was characterized by considerable temporal variability throughout the LM, with significant departures from the mean state during both the Medieval Climate Anomaly (MCA) and the Little Ice Age (LIA). The monsoon was intensified during the LIA over the central and western parts of tropical South America and the South Atlantic Convergence Zone (SACZ) was displaced to the southwest. These centennial-scale changes in monsoon intensity over the LM are underestimated in climate models, complicating the attribution of changes on these timescales to specific forcings and pointing toward areas of important model development. 
https://doi.org/10.5194/cp-2022-6

Preprint. Discussion started: 31 January 2022

(c) Author(s) 2022. CC BY 4.0 License.

(c) (i)

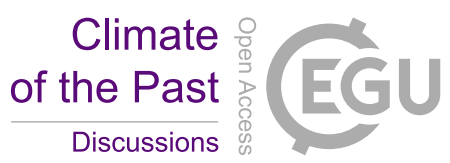

\section{Introduction}

The annual hydrologic cycle in northern and central South America is dominated by distinct wet and dry seasons

35 following the development and demise of the South American Monsoon System (SAMS) (Vera et al., 2006). The mature phase of the monsoon occurs during the austral summer in December, January, and February (DJF) when the region receives the majority of its annual precipitation (Zhou and Lau, 1998; Garreaud et al., 2009). Monsoon rainfall is critical to many environmental services, the integrity of indigenous traditions and practices, drinking water, agriculture, and hydroelectric power generation, all of which are vulnerable to changes in the monsoon system. Although historical hydroclimate observations do exist from this region over the $20^{\text {th }}$ century, such records are not long enough to characterize multidecadal to centennial changes, which are critical for interpreting and constraining projections of future change.

Observational records have, however, aided in defining some of the characteristics of present-day SAMS dynamics. The onset of the SAMS is initiated by the increase in austral summer insolation over the southern hemisphere driving the seasonal southward progression of the Intertropical Convergence Zone (ITCZ) and strengthening the onshore flow of moisture from the tropical Atlantic toward the South American continent (Zhou and Lau, 1998). As the monsoon matures, near-surface easterly winds are channeled southeastward along the Andes mountains into the South American LowLevel Jet (SALLJ). The SALLJ transports moisture into the subtropics and feeds the South Atlantic Convergence Zone (SACZ), an axis of NW-SE convective activity in southeastern Brazil (Kodama, 1992, 1993, Carvalho et al., 2004).

Convection over the Amazon, Andes, and to a lesser extent, in the SACZ generates diabatic heating anomalies via

50 the release of latent heat. This triggers an easterly Rossby wave response known as the Bolivian High - Nordeste Low (BHNL) system (Lenters and Cook, 1997; Chen et al., 1999) and leads to subsidence to the east of the monsoon heating region over northeastern Brazil and the tropical South Atlantic, intensifying the South Atlantic Subtropical Anticyclone (SASA) (Rodwell and Hoskins, 2001). The strength of this monsoonal circulation varies on multiple timescales and is modulated interannually by the El Niño-Southern Oscillation (ENSO) phenomenon (Vuille and Werner, 2005; Garreaud et al., 2009;

55 Sulca et al., 2018; Cai et al., 2020) and on decadal to multidecadal timescales by modes of variability in both the Atlantic and Pacific, via perturbations of the local Walker and Hadley circulation (He et al., 2021).

Because these dynamics are linked to hydroclimatic change, the recent development of paleo hydroclimatic records from the SAMS region has extended our characterization of monsoon variability in the past with increasing spatial and temporal resolution. Stable oxygen isotope records form the basis for much of our understanding about past variability of the SAMS. The existing subdecadally resolved oxygen isotope records spanning the last millennium (LM, 850-1850 CE) are known to be representative of regional variability related to the summer monsoon (Vuille et al., 2003; Vuille and Werner, 2005). High-resolution oxygen isotope paleorecords are widely available from archives in South America: ice cores in Andean glaciers (e.g. Thompson et al., 1985; Vimeux et al., 2009), lake sediment cores from closed basin lakes (e.g., Bird et al. 2011), speleothems from karstic regions (e.g., Novello et al., 2018; Campos et al. 2019), and tree rings in high-altitude 65 regions (e.g., Baker et al., 2015; Rodriguez-Caton et al., 2022). 
In tropical South America, isotopic fractionation through Rayleigh distillation occurs during rainout along moisture trajectories where it is governed by convective processes rather than temperature changes. Local anti-correlation of precipitation amount with isotopic values due to the amount effect has also been documented, especially in close proximity to the Atlantic coast (Vuille et al., 2003; Moquet et al., 2016). More recent studies document the importance of an interplay

70 of fractionation processes, finding that oxygen isotopes integrate various controls on tropical hydroclimate, such as circulation changes, energetic processes, microphysical processes, and local environmental conditions (Risi et al., 2008; Konecky et al., 2019).

The current interpretation of isotopic signatures in South American paleorecords therefore allows insight into both local climate and regional atmospheric circulation. Along the moisture trajectory, convective rainout follows a Rayleigh

75 Distillation model (Dansgaard, 1964; Vuille et al., 2012) with the remaining water vapor becoming isotopically depleted downstream of the source. Due to evapotranspiration within the Amazon basin, a reduced depletion gradient is seen across the Amazon (Salati et al., 1979; Ampuero et al., 2020). Secondary effects also modify isotopic variability during the monsoon season, such as mixing of air masses with different moisture sources (e.g. from the tropical North or South Atlantic) or significant rainfall contributions from other circulation systems outside of the monsoon season (Cruz et al.,

80 2005; Apaéstegui et al., 2018). Ultimately, the degree of rainout upstream associated with the SAMS is the dominant common denominator influencing all records within the monsoon domain, explaining why records from different archives located in different environments separated by thousands of miles share a common signal (Vuille et al., 2012; Campos et al., 2019; Ampuero et al., 2020; Novello et al., 2021).

The wealth of information archived by paleoclimate records is clear, but the balance between site-specific and

85 regional information is unique to each record. Today, the growing catalog of existing records is ripe for a more systematic analysis that can extract coherent regional changes. To isolate the influence of the SAMS requires the application of a network analysis such as Monte Carlo Empirical Orthogonal Function (MCEOF) decomposition (Anchukaitis and Tierney, 2013). A coherency analysis, demonstrated by previous network studies both in South America and in other regions, is uniquely capable of highlighting the regional system variability while minimizing the influence of local climate at individual 90 proxy sites (Anchukaitis and Tierney, 2013; Tyler et al., 2015; Deininger et al., 2017; Falster et al., 2018; Campos et al., 2019; Novello et al., 2021).

Campos et al. (2019) describe characteristics of the monsoon system with an emphasis on the temporal variability as captured by leading modes of variability from a multi-proxy network. Their analysis characterizes the first two modes of variability as well as critical time periods detected by the principal component analysis and compares these to EOFs of 95 present-day precipitation and other hydroclimate records from the region. Atwood et al. (2021) also perform an EOF analysis across the global tropics using hydroclimate proxies for the LM, including over tropical South America. While both these studies provide valuable new insight into South American hydroclimate during the LM, they are both based on a network of sites that lacks data in the core monsoon region of the southwestern Amazon as well as at the most distal monsoon sites in the southern tropical Andes. 
https://doi.org/10.5194/cp-2022-6

Preprint. Discussion started: 31 January 2022

(c) Author(s) 2022. CC BY 4.0 License.

(c) (i)

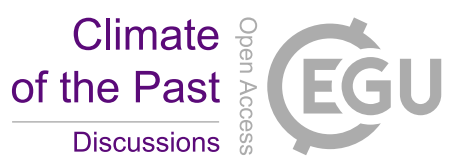

Additionally, while the dynamical characteristics of the SAMS climatology are well known, a mechanistic understanding of the factors underlying the regional isotopic variability has yet to be established. The emergence of new tropical isotopic records enables the reconstruction of a more regionally coherent picture of past hydroclimatic change than the relatively heterogeneous modes described by proxies recording local precipitation only. Combining this network approach with an analysis of isotope-enabled climate model simulations allows mechanisms of past change to be identified and for proxy records to be dynamically contextualized within past variability.

We present an analysis of the SAMS using a proxy network derived solely from oxygen isotope records covering the LM, all located within the SAMS domain. Included in this analysis are three records that have not been used in any prior proxy network analysis (Boto, PIM4, MV; see Table 1) and help improve the spatial coverage of monsoon impacts in hitherto undersampled regions. We show the first two common modes of isotopic variability and contextualize them within our current understanding of present-day monsoon dynamics. In parallel, an identical analysis was performed on simulations from two isotope-enabled climate models and compared with the results from the proxy analysis. Finally, we interpret the monsoon behavior during the Medieval Climate Anomaly (MCA, 850-1160 CE) and Little Ice Age (LIA, 1489-1850 CE) (time periods as defined in Campos et al., (2019)), which emerge as periods of multi-centennial deviations from the mean state of the LM.

\section{Data and Methods}

\subsection{MCEOF analysis approach}

The variability of the SAMS was investigated by decomposing oxygen isotope data from both paleoclimate records and model simulations into the leading modes of variability using a MCEOF analysis originally developed for the analysis of West African lacustrine sediments (Anchukaitis and Tierney, 2013). Since its development, this technique has been applied to a variety of proxy networks, including in South America by Campos et al. (2019) and Novello et al. (2021). The EOF decomposition allows for discrete characteristics of monsoon system variability to be isolated, while the application of a Monte Carlo method conserves uncertainties associated with the age models of the individual paleoclimate records used as input. For all EOF analyses, the first two modes were considered significant using North's rule of thumb (North et al., 1982) and the fact that they aligned with a dynamically and physically plausible interpretation.

The fourteen records used in this analysis were derived from raw samples from varied archives of speleothems $(n=12)$, an ice core $(n=1)$, and authigenic calcite in a lake sediment core $(n=1)$. These records were identified as: PAR (composed of PAR01 + PAR03), PAL (composed of PAL3 + PAL4), Pumachocha, P00-H1, MV (composed of MV1 + MV3), PIM4, DV2, SBE3 + SMT5, Quelccaya, ALHO6, TM0, Boto (composed of Boto1 + Boto3 + Boto7 + Boto10), JAR (composed of JAR1 + JAR4), and CR1. For each sample, 1,000-member ensembles of age models were developed based on

130 a Monte Carlo resampling from a Gaussian distribution of the one-sigma measurement uncertainty of each age tie point. Each age model ensemble member was linearly interpolated between depth/age points and fit by the depth/time series from 
https://doi.org/10.5194/cp-2022-6

Preprint. Discussion started: 31 January 2022

(c) Author(s) 2022. CC BY 4.0 License.

(c) (1)

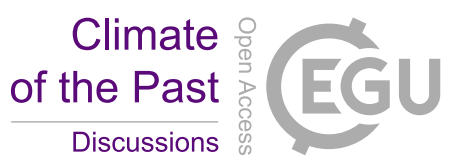

each proxy sample to establish an ensemble of proxy time series (Deininger et al., 2017; Campos et al., 2019; Novello et al., 2021). In cases where individual samples did not span the entire time period of study, multiple shorter samples were spliced together. Records were resampled to annual resolution and truncated, resulting in a 1,000-member ensemble of fourteen complete records spanning the LM. Each of the 1,000 ensemble sets of oxygen isotope records was subsequently decomposed into leading modes of spatial and temporal variability, and the median of the ensemble modes was analyzed in this study (Anchukaitis and Tierney, 2013; Deininger et al., 2017).

\subsection{Record processing}

The spatial distribution of the proxy archives is shown in Fig. 1 and more detailed information is provided in

140 Table 1. Much of the data used here has been published with the exception of the MV30 sample, which was collected in the Mata Virgem Cave in Brazil (Azevedo et al., 2019). Published data were accessed through the National Centers for Environmental Information (NCEI) Paleo Data server (https://www.ncdc.noaa.gov/paleo-search/) or through the University of São Paolo Geosciences speleothem database. Eleven of the records used for this analysis have established age chronologies using $\mathrm{U} / \mathrm{Th}$ radioisotope dating and were found to be sub-decadally to annually resolved. The remaining three records in the network were published with annual resolution (Quelccaya, Pumacocha, ALHO6) determined from visible stratigraphy and confirmed with radiometric dating where possible (Bird et al., 2011; Thompson et al., 2013; Novello et al., 2016). These records were interpolated to exact calendar years where necessary, with the finalized record duplicated for each ensemble member. For those samples that do not cover the entire LM, composite records were synthesized by merging multiple samples from the same cave system (indicated in Table 1) and samples with hiatuses were interpolated to ensure a continuous record for analysis. 


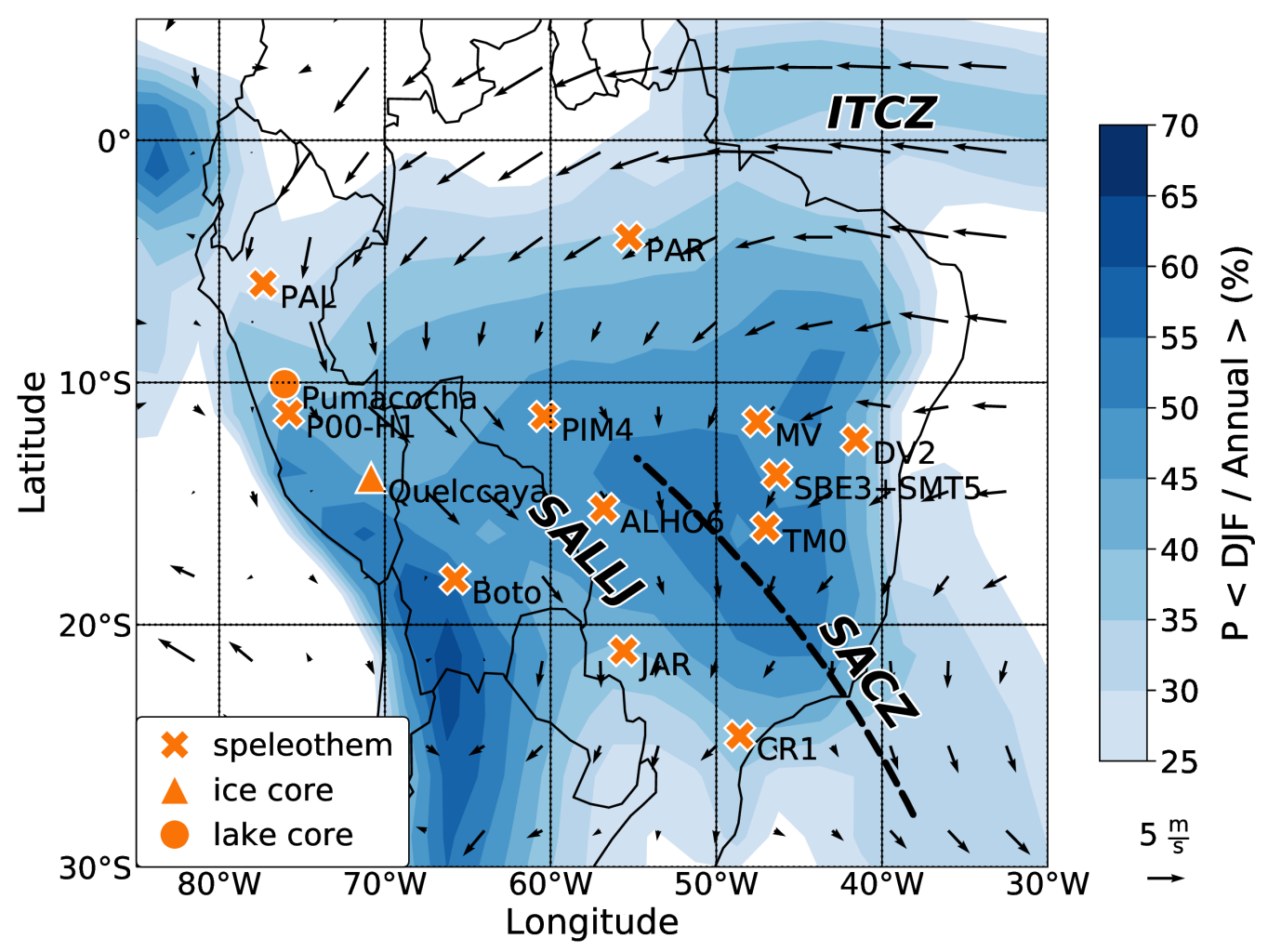

Figure 1: Oxygen isotope proxy network spanning the South American Monsoon domain (details presented in Table 1). Color shading represents the percent of annual precipitation falling in December to February (DJF, austral summer) based on GPCP data (1979-2019). Vectors represent the low-level (850 hPa) DJF wind field based on ERA5 data (1979-2019). Major dynamical features are highlighted. 


\begin{tabular}{|c|c|c|c|c|c|}
\hline Sample ID & Record & $\begin{array}{l}\text { Sampling } \\
\text { res. (avg) }\end{array}$ & Location & $\begin{array}{l}\text { Elevation } \\
\text { (above sea } \\
\text { level) }\end{array}$ & Reference \\
\hline PAR01 + PAR03 & Paraíso Cave & $7 \mathrm{yrs}$ & $4.00^{\circ} \mathrm{S}, 55.27^{\circ} \mathrm{W}$ & $60 \mathrm{~m}$ & Wang et al., 2017 \\
\hline PAL3 + PAL4 & Palestina Cave & 5 yrs & $5.92^{\circ} \mathrm{S}, 77.35^{\circ} \mathrm{W}$ & $870 \mathrm{~m}$ & Apaéstegui et al., 2014 \\
\hline Pumacocha & Laguna Pumacocha & $1 \mathrm{yr}$ & $10.07^{\circ} \mathrm{S}, 76.06^{\circ} \mathrm{W}$ & $4,300 \mathrm{~m}$ & Bird et al., 2011 \\
\hline MV1 + MV30 & Mata Virgem Cave & $2 \mathrm{yrs}$ & $11.37^{\circ} \mathrm{S}, 47.29^{\circ} \mathrm{W}$ & $380 \mathrm{~m}$ & Azevedo et. al., 2019 \\
\hline PIM4 & Cuíca Cave & 3 yrs & $11.40^{\circ} \mathrm{S}, 60.38^{\circ} \mathrm{W}$ & $310 \mathrm{~m}$ & Della Libera et al., 2022 \\
\hline DV2 & Diva Cave & 4 yrs & $12.36^{\circ} \mathrm{S}, 41.57^{\circ} \mathrm{W}$ & $700 \mathrm{~m}$ & Novello et al., 2012 \\
\hline SBE3 + SMT5 & $\begin{array}{l}\text { São Bernardo, São Matheus } \\
\text { Caves }\end{array}$ & $1.2 \mathrm{yrs}$ & $13.81^{\circ} \mathrm{S}, 46.35^{\circ} \mathrm{W}$ & $631 \mathrm{~m}$ & Moquet et al., 2016; Novello et al., 2018 \\
\hline TM0 & Tamboril Cave & 3 yrs & $16.00^{\circ} \mathrm{S}, 47.00^{\circ} \mathrm{W}$ & $575 \mathrm{~m}$ & Wortham et al., 2017; Fohlmeister et al., 2020 \\
\hline $\begin{array}{l}\text { Boto1 }+ \text { Boto3 }+ \\
\text { Boto7 }+ \text { Boto10 }\end{array}$ & $\begin{array}{l}\text { Umajalanta-Chiflonkhakha } \\
\text { Caves }\end{array}$ & 2 yrs & $18.12^{\circ} \mathrm{S}, 65.77^{\circ} \mathrm{W}$ & $2,650 \mathrm{~m}$ & Apaéstegui et al., 2018 \\
\hline JAR1 + JAR4 & Jaraguá Cave & $3 \mathrm{yrs}$ & $21.08^{\circ} \mathrm{S}, 55.58^{\circ} \mathrm{W}$ & $570 \mathrm{~m}$ & Novello et al., 2018 \\
\hline CR1 & Cristal Cave & $2.7 \mathrm{yrs}$ & $24.58^{\circ} \mathrm{S}, 48.58^{\circ} \mathrm{W}$ & $130 \mathrm{~m}$ & Vuille et al., 2012 \\
\hline
\end{tabular}

Table 1: Oxygen isotope proxy network.

Samples actively growing upon collection (P00-H1, CR1, SBE3, PIM4) were assigned an age tie point without

error to the year of collection at zero depth to anchor the chronology (Anchukaitis and Tierney, 2013). Some age points of the TM0 record were published with multiple samples indicated for a given depth; the employed final dates were calculated as the mean of the samples analyzed. Age models were constructed with strict superposition enforcement. Those age ties with processing errors or dates leading to age reversals were excluded from analysis to ensure superposition of the age chronologies (JAR1, JAR4, MV30). In the Monte Carlo resampling, simulated age tie values that violated superposition

190 were rejected and recalculated. Isotopic measurements excluded from previously published analyses were likewise excluded here (SBE3, PIM4), as were individual data points exceeding 3 standard deviations (MV30). Multiple isotopic measurements from a single depth were averaged to establish one value per depth (PAL3).

\subsection{Gap interpolation}

Samples that contained hiatuses (SBE3, PIM4) or multiple discontinuous samples (MV1, MV30) had gaps filled 195 after pre- and post-gap segments underwent ensemble generation. Gap filling proceeded in two steps: (1) a linear interpolation was used to fill gaps in the time series; and (2) the isotopic value for each year was resampled from a normal distribution centered on the interpolated point from a normal distribution scaled to the average standard deviation of the thirty years before and after the gap. This procedure bridges a gap in the data in order to meet the continuous data 
https://doi.org/10.5194/cp-2022-6

Preprint. Discussion started: 31 January 2022

(c) Author(s) 2022. CC BY 4.0 License.

(c) (i)

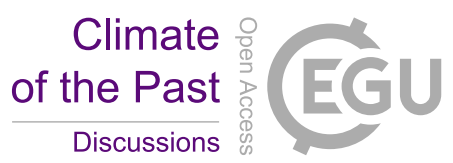

requirement of the MCEOF procedure while also maintaining the intrinsic characteristics of variability present in a given record. For bridging the gap between the MV1 and MV30 samples, MV30 was bias-corrected to have the same mean as MV1; the two records were standardized, and the gap was filled as described above. As a result of the Monte Carlo age model resampling, a small number of ensemble members returned samples that overlap or do not have a gap in data, in which case the samples were merged or taken to be continuous, respectively.

\subsection{Sample merging}

Six of the isotopic records used in this analysis were composited from multiple raw samples (MV, JAR, PAR, SBE3+SMT5, PAL, Boto). As in Novello et al. (2021), composite records were formed by merging individual ensemble members using three steps: (1) ensemble members in the period of overlap were fit with a cubic spline function and synchronized to annual resolution; (2) each time series was standardized by its respective mean and standard deviation during the LM; and (3) samples were averaged together to create one time series that was reconstructed by inverting the normalization of the record with the longest coverage during the LM. Finally, records were truncated to strictly cover the LM and resampled to annual resolution.

\subsection{Isotope-enabled model analysis and pseudoproxy experiments}

Two isotope-enabled coupled climate models were used to investigate mechanisms associated with climate variability over the LM: (1) the water isotope-enabled NCAR Community Earth System Model (iCESM) (Brady et al., 215 2019); and (2) the Goddard Institute for Space Studies coupled ocean-atmosphere model (GISS-E2-R) (Schmidt et al, 2007; Schmidt et al., 2014; Colose et al., 2016a,b). In these isotope-enabled simulations, stable oxygen and hydrogen isotopes have been added as tracers of the hydrological cycle, enabling a more direct comparison of model and proxy data and a better understanding of water cycle dynamics. The iCESM was run with $1.9^{\circ} \times 2^{\circ}$ horizontal resolution and 30 vertical levels. Analyzed simulations were from the isotope-enabled Last Millennium Ensemble project, including full and single forcing (volcanic, solar, and orbital) experiments following the CESM Last Millennium Ensemble (iLME, Otto-Bliesner et al., 2016; Brady et al., 2019). The GISS-E2-R model was run at $2^{\circ} \times 2^{\circ}$ horizontal resolution with 40 vertical levels. We analyzed the simulation from the E4rhLMgTKck experiment (Blake et al., 2018), which contains a full suite of transient external forcings. Both models include forcings selected from the PMIP3 Last Millennium forcing set v1.0 (Schmidt et al., 2011), although they rely on somewhat different forcing reconstructions.

The iCESM is known to have a negative isotope bias, overestimating the strength of the relationship between precipitation and $\delta^{18} \mathrm{O}$. This is particularly true at higher rainfall rates, though spatial patterns are consistent with observations and values are similar to the proxy data (Brady et al., 2019; Stevenson et al., 2019). Isotopes in the GISS-ER2$\mathrm{R}$ are highly correlated with observations, but show a weak dependence to changes in temperature and precipitation (Schmidt et al., 2007); the GISS-E2-R reproduces key isotopic features of the South American monsoon (Colose et al., 2016a). 
https://doi.org/10.5194/cp-2022-6

Preprint. Discussion started: 31 January 2022

(c) Author(s) 2022. CC BY 4.0 License.

(c) (i)

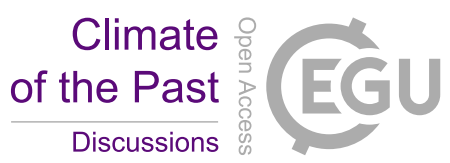

We extracted the leading EOFs from two model-derived datasets that are complimentary in their comparison with proxy records of the monsoon domain: one based on spatially continuous data across the full monsoon domain and one using a pseudoproxy experiment approach (Smerdon, 2012). In both cases the EOF was based on precipitation-weighted $\delta^{18} \mathrm{O}$ during DJF, which corresponds to the mature monsoon season when isotopic proxies receive the largest fraction of their total annual precipitation (Fig. 1).

For the spatially continuous EOF approach, data from both the full-forcing ensemble members of the iCESM and GISS-E2-R model as well as the single forcing simulations of the iLME using the volcanic, solar, and orbital forcings were used. The land use/land cover and greenhouse gas forced ensemble members do not exhibit significant change in the forcing data sets during the LM and were thus excluded from the analysis.

For the pseudoproxy approach, the iLME full-forcing experiment was used and a spatial sub-sampling was applied by extracting an ensemble of pseudoproxies from the real-world proxy locations. These subsampled time series were then added to randomly generated Gaussian white noise, effectively scaling the model-simulated isotopic time series to more realistically replicate the internal variability of the proxy systems. In our specific experiment, the white noise was used to represent unresolved sub-grid scale processes (Berner et al., 2017). While this representation cannot fully account for the cascading influence of sub-grid scale processes resulting from external forcings, it does allow the EOF analysis to decompose spatial modes from model data based on a broader representation of multi-frequency (i.e. multi-scale) information as captured by the proxy record. Following Smerdon (2012), this white noise perturbation was drawn from a Gaussian distribution and added to model-derived pseudoproxy isotopic time series using signal-to-noise (SNR) ratios of 0.5 and 0.25. Previous PPE studies focused on temperature have found SNR = 0.5 to be a realistic estimate (Mann et al., 2007; Smerdon, 2012; Wang et al., 2014). Given the larger variability of precipitation compared to temperature, SNR $=0.5$ and SNR $=0.25$ were considered here to be bounding estimates of SNR for hydrological proxies, though further work to understand noise in hydroclimate proxies is important for a more sophisticated hydrological PPE.

\subsection{Present-day composite analysis}

Our physical interpretations of the leading MCEOFs are based on modern observations for the DJF season. The upper tropospheric (200 hPa) wind field data are based on ERA5 Reanalysis for present-day (1979-2019) (Hersbach et al., 2020). Precipitation station data were extracted from GHCN (Menne et al., 2012) and supplemented with data obtained from the national weather services of Bolivia, Peru, and Brazil. A time series of seasonal (DJF) precipitation at the site of each proxy record was created based on the median of all stations available within a $2^{\circ}$ radius. The data period was $1975-2014$ for all locations, except for those near the PIM4 site, where four years of data are missing (1998, 2002, 2003, 2004). Outgoing longwave radiation (OLR), a commonly employed proxy for tropical convection, was analyzed using the NOAA interpolated OLR data set (Liebmann and Smith, 1996) for the same period as the precipitation data. OLR data for the SACZ region was decomposed using an EOF decomposition and the resulting PC1 correlated in space with the gridded OLR product and precipitation data. 
https://doi.org/10.5194/cp-2022-6

Preprint. Discussion started: 31 January 2022

(c) Author(s) 2022. CC BY 4.0 License.

(c) (i)

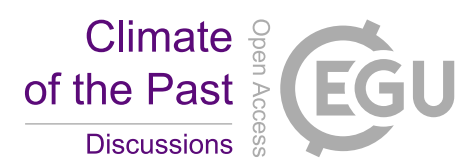

A composite analysis was performed for the MCA (850-1160 CE) and LIA (1489-1850 CE) periods based on both paleoclimatic records and climate model data. The MCA and LIA periods were defined using the Campos et al. (2019) change point analysis, which highlighted major departures in South American hydroclimate. Anomalies were calculated for these periods relative to the LM. Atmospheric circulation and hydroclimate diagnostics of mid-tropospheric vertical velocity $\left(\omega 500,500 \mathrm{hPa}\right.$ ), precipitation, and precipitation-weighted $\delta^{18} \mathrm{O}$ of precipitation were analyzed by averaging these variables for the mature monsoon season (DJF) for the three full-forcing ensemble members from the iLME experiment. Proxy composites were calculated during the above time periods from the average of annually interpolated composite records generated for the MCEOF analysis. Statistical significance was calculated using a two-tailed students t-test and evaluated at $p \leq 0.1$.

\section{Results}

\subsection{MCEOF results from proxy network}

The results of the proxy-based MCEOF analysis are shown in Fig. 2. Loadings are weighted by the correlation between the individual proxy records and the corresponding principal component (PC) time series for that mode.
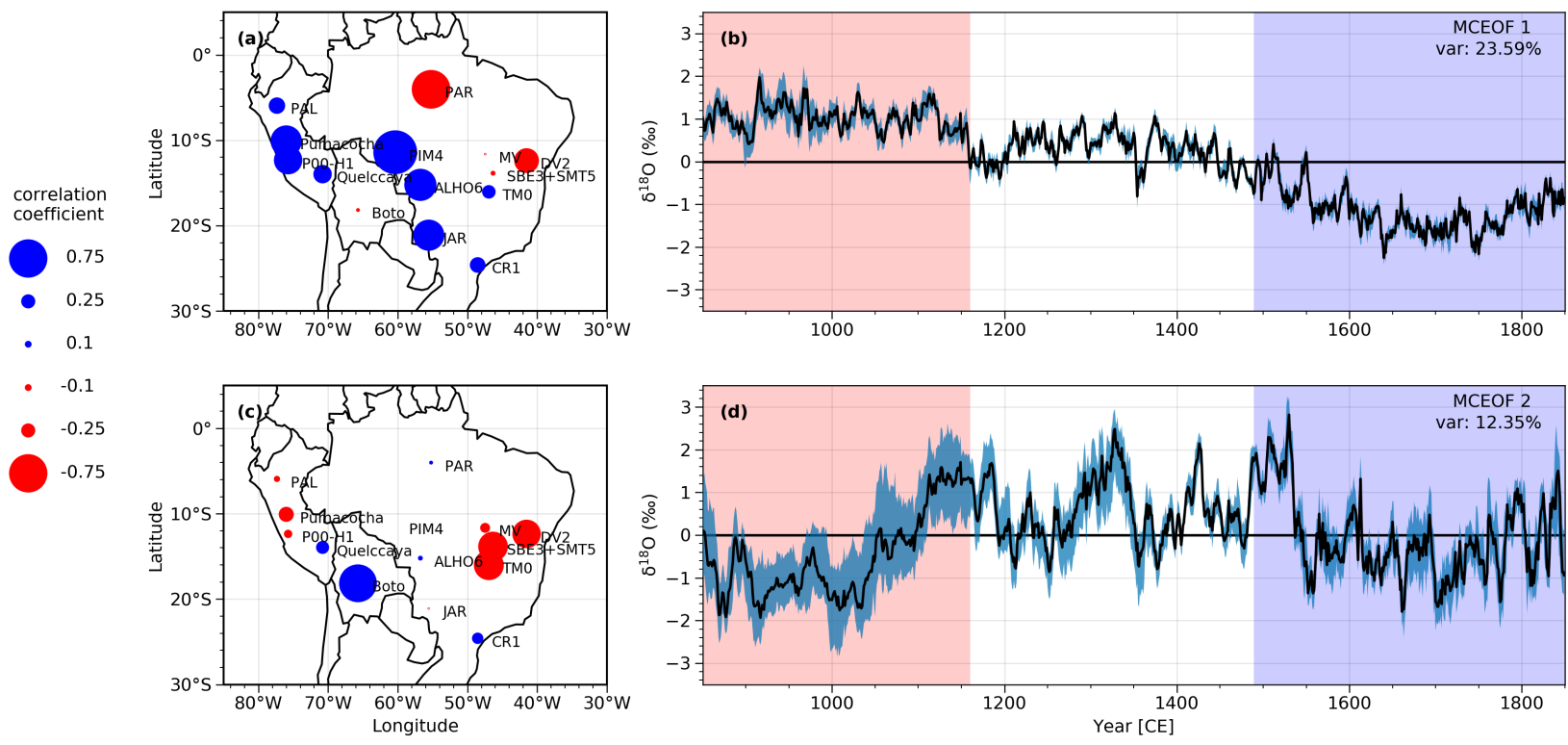

Figure 2: MCEOF decomposition of the oxygen isotope proxy network. a) MCEOF1. Spatial pattern corresponds to ensemble median point loading correlations with the PC time series; b) PC1. Shading indicates the total envelope of ensemble variability; c) as in a) but for MCEOF2; d) as in b) but for PC2. Pink/blue shading in b) and d) highlight the MCA/LIA periods, respectively. 
https://doi.org/10.5194/cp-2022-6

Preprint. Discussion started: 31 January 2022

(c) Author(s) 2022. CC BY 4.0 License.

(c) (i)

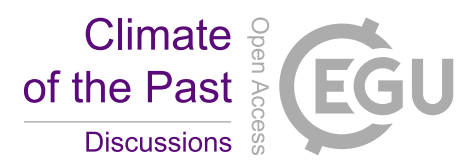

The leading mode of isotopic variability explains approximately $24 \%$ of the total variance. This mode is interpreted as representative of the isotopic variability in the core monsoon region and is shown to vary on centennial timescales. The majority of the proxy records in the region of strong monsoonal convection (the center and western region of the monsoon domain) vary in phase, while the northeastern/eastern records are negatively correlated with PC1, implying that they vary out of phase (Fig. 2a). The PC time series indicates that records over the southwestern SAMS domain exhibited

285 anomalously positive isotopic values during the MCA and anomalously negative values during the LIA, while records to the northeast show opposite isotopic anomalies (Figs. 2a-b).

The second mode explains approximately $12 \%$ of the total variance and exhibits the strongest cluster of loadings in central-eastern Brazil, a region influenced by the SACZ (Fig. 2c). Proxy records that project strongly onto this mode influenced by SACZ activity include ALHO6, SBE3+SMT5, TM0 and DV2, while records over the southern central Andes 290 (Quelccaya and especially Boto) vary out of phase. There is a prolonged negative excursion of PC2 during the core of the LIA (approximately 1550 - 1750 CE) (Fig. 2d). The Boto record, a regional anomaly, loads strongly onto this mode, indicating a strong local response inversely correlated with spatiotemporal dynamics that are primarily dominant in southeastern Brazil.

\subsection{Model results}

\section{3.2.1 Continuous domain results}

EOF1 in the full-forcing simulations with GISS and iCESM shows the same monsoon footprint as present in the proxy-based MCEOF1, albeit with the region of positive correlations associated with the first PC (Figs. 3a-b) encompassing a broader area. The explained variance of the proxy-based MCEOF1 is matched by the GISS model and exceeded by the iCESM EOF1 (33\% in iCESM versus 24\% in the proxy data). The first mode across all experiments (full-forcing and single forcings) represents the region characterized by convective activity of the monsoon core, reproducing well the proxy-based MCEOF1. In iCESM, the highest loadings are located over the central Amazon, while in the GISS model, they are centered farther west, over the eastern flank of the Andes. An antiphased region over northeastern Brazil is present in the iCESM experiments, consistent with the proxy-based MCEOF1 and indicative of the BH-NL-induced east-west precipitation and isotope dipole (Cruz et al., 2009; Cheng et al., 2013). This characteristic aspect of the SAMS is notably absent in the GISS EOF1, where positive loadings extend across the entire domain analyzed. 

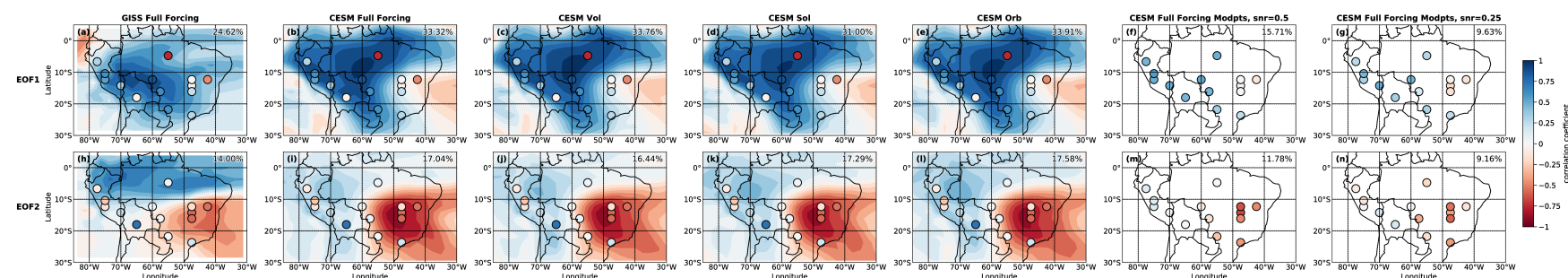

Figure 3: Comparison of proxy- and model-derived leading modes of isotopic variability. a) EOF1 from GISS full forcing experiment (shading) overlaid with proxy-based MCEOF1 (colored circles), b) as in a) but for iCESM full forcing experiment, c) as in a) but for iCESM volcanic forcing experiment, d) as in a) but for iCESM solar irradiance experiment, e) as in a) but for iCESM orbital forcing experiment, f) iCESM EOF1 derived from grid cells corresponding to proxy locations only, with white noise added ( $\mathrm{SNR}=\mathbf{0 . 5}$ ), g) as in $\mathrm{f}$ ) but for $\mathrm{SNR}=\mathbf{0 . 2 5}$. h-n) as in a-e) but for EOF2.

The largest loadings present in EOF2 are located in central-eastern Brazil, the region corresponding to SACZ activity, again consistent with the proxy-based EOF2 (Fig. 2c), although the loadings over the northern tropical Andes differ. The second model-derived mode explains $14 \%$ and $17 \%$ of the data in GISS and iCESM models, respectively (Figs. 3h-i), a somewhat larger explained variance than in the proxy-based MCEOF2 ( 12\%). Nevertheless, the representation of SACZ variability present in all models indicates models represent the dynamics of this region well. The emergence of isotopic variability over the SACZ-region in this second mode is more apparent in the iCESM results than the GISS model-derived EOF2. The GISS model shows a decreased explained variance of this second mode relative to the iCESM that is more on par with the partitioning of the proxy-based MCEOF2.

The EOF decomposition of the iLME single-forcing experiments (Figs. 3c-e, j-l) yields only minor departures from patterns of the full-forcing experiment and replicates the proxy-based MCEOF patterns equally well. This underscores the inherent stability of the spatial characteristics of these modes of the SAMS, regardless of the external forcing applied to the experiment. The presence of almost identical leading modes across all single-forcing experiments indicates that these modes are intrinsic to the system itself, rather than a consequence of external forcings and likely result from time-invariant boundary conditions such as the shape and latitudinal extent of the continent, the Andean orography, and the intersection of the landmass with the equatorial trade winds.

\subsubsection{Pseudoproxy experiment analysis}

The EOF decomposition of the pseudoproxy network derived from the addition of white noise to the modeled isotopic time series results in a reduction of explained variance relative to the proxy-based modes, likely indicating the experimental SNRs applied to this region were too small relative to the real climate system. Despite the decrease in explained variance, the spatial patterns of EOF1 and 2 from the pseudoproxy network replicate those described above from both proxies and models. The main monsoon and SACZ footprints in EOF1 and EOF2 are readily apparent using a SNR = 0.5. Increasing the amount of white noise added to the pseudoproxy records to $\mathrm{SNR}=0.25$ results in a decrease of the total variance explained (EOF1: $\sim 16$ to 10\%; EOF: 12\% to 9\%) and the overall spatial patterns of the modes becoming more 
https://doi.org/10.5194/cp-2022-6

Preprint. Discussion started: 31 January 2022

(c) Author(s) 2022. CC BY 4.0 License.

(c) (1)

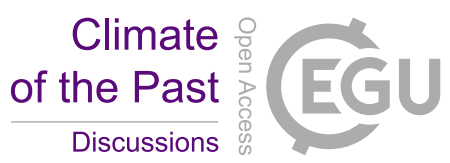

regional loading in the region of central-eastern Brazil associated with the SACZ (Fig. 3n). This SNR sensitivity test confirms the robustness of the modeled results and the model's ability to reproduce the main modes of South American monsoon variability in a pseudoproxy framework. The larger explained variance of the proxy-based modes relative to those from the pseudoproxy network of SNR $=0.5$ suggests that the noise characteristics of the SAMS proxy network may be very region- and proxy-specific, and that isotopic proxy networks in some cases may exhibit less noise than currently established within the literature for other multiproxy networks (Mann et al., 2007; Smerdon, 2012). More detailed estimates of environmental SNRs would open the possibility for closer calibration between proxy network analysis and estimation of regional climate variability via pseudoproxy experiments.

\section{Discussion}

\section{4.1 Proxy-based modes of monsoon variability}

\subsubsection{MCEOF1}

The two modes extracted from the proxy network via MCEOF correspond to distinct patterns that are inherent to the SAMS. EOF1 represents the isotopic response to the Bolivian High-Nordeste Low (BH-NL) system: an upper tropospheric Rossby wave train induced by diabatic heating from convection over the core monsoon region in the western 350 Amazon (Lenters and Cook, 1997; Chen et al., 1999) (Fig. 4). 


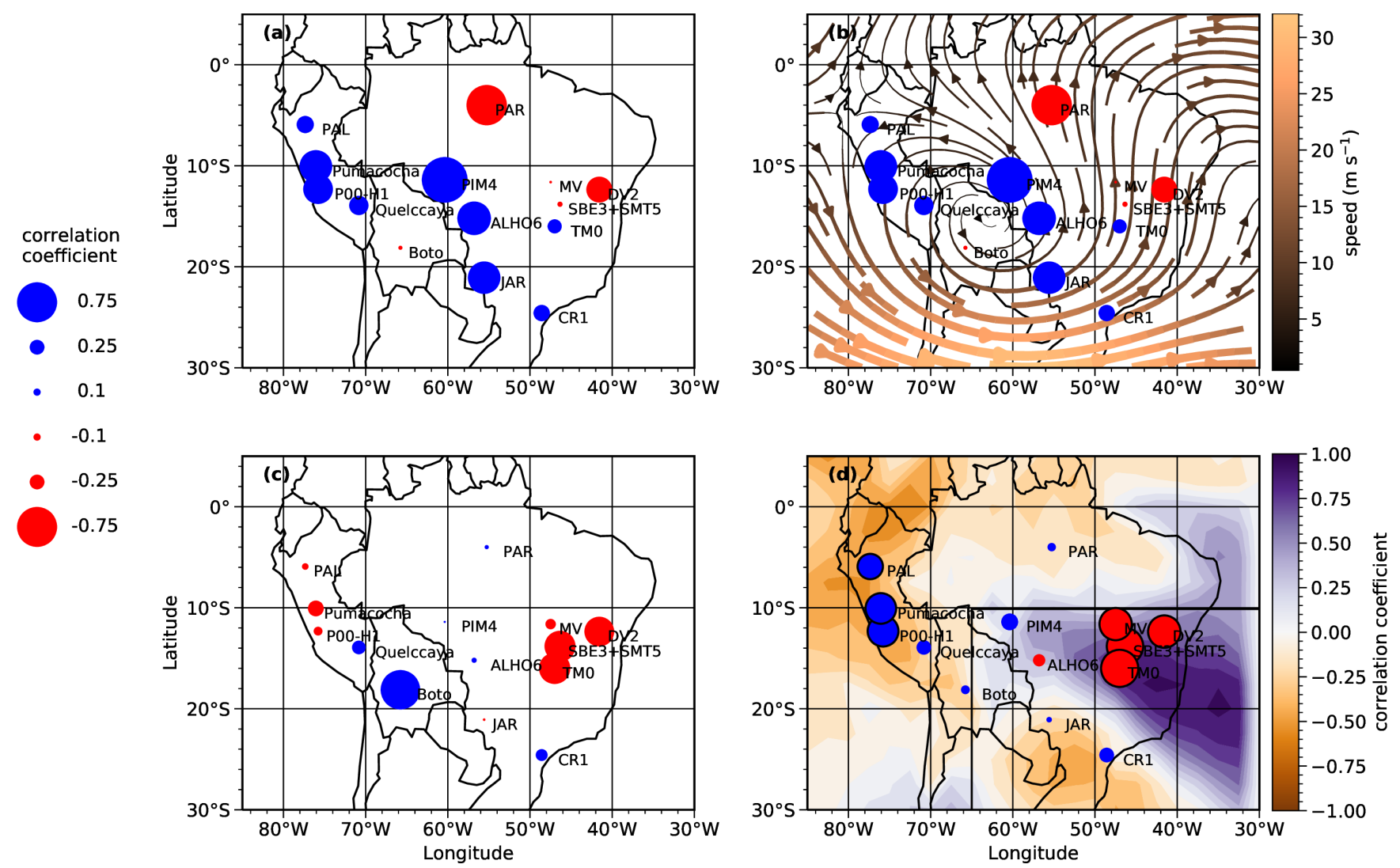

Figure 4: MCEOF patterns and their corresponding dynamic interpretations. a) MCEOF1 loading pattern; b) upper-level (200 hPa) DJF streamlines from ERA5 reanalysis (1979-2019); c) MCEOF2 loading pattern; d) spatial correlation of DJF OLR field with the PC1 of OLR variability derived from the SACZ region (black box). Colored circles indicate the correlation of local precipitation derived from station data with PC1 of the OLR decomposition over the SACZ region.

This stationary wave propagates downstream of deep tropical convection, establishing an upper-level anticyclone over Bolivia, known as the 'Bolivian High' and is balanced by enhanced subsidence over northeastern Brazil where a deep trough develops, known as the 'Nordeste Low.' This mechanism results in a precipitation dipole between the tropical Andes/ western Amazon basin and northeastern Brazil, which has been documented on multiple timescales, including orbital (Cruz et al., 2009; Cheng et al., 2013), centennial (Apaéstegui et al., 2018), multidecadal (Campos et al., 2019), interannual (Vuille and Werner, 2005) and intraseasonal (Sulca et al., 2016). Long-term departures exhibited in PC1 support the current understanding of the MCA as a period characterized by relatively weak large-scale monsoon circulation, while the SASM was intensified during the LIA (Novello et al., 2012; Rojas et al., 2016). The reduced departures from the mean of PC1 during the MCA when compared to the LIA support evidence from individual proxy records that the monsoon intensification during the LIA represented a stronger regional departure from the monsoon mean state than the relatively subdued weakening during the MCA (Vuille et al., 2012). Here, monsoon intensification (weakening) refers to the intensification (weakening) of the upper-tropospheric BH-NL system (Chen et al., 1999; Sulca et al. 2016; Campos et al., 2019) and its surface expression of enhanced monsoon precipitation over the western Amazon/tropical Andes and enhanced aridity over 
https://doi.org/10.5194/cp-2022-6

Preprint. Discussion started: 31 January 2022

(c) Author(s) 2022. CC BY 4.0 License.

\section{(c) (1)}

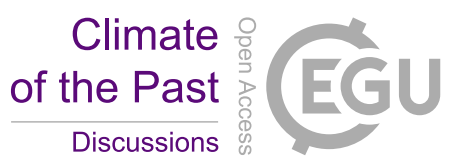

northeastern Brazil. Changes in Rayleigh fractionation of water vapor from condensation and rainout during strong/weak convection results in this precipitation dipole being prominently displayed in stable oxygen isotopes of precipitation (Vuille and Werner, 2005; Sturm et al., 2007).

\subsubsection{MCEOF2}

The second mode captures the variability of the SACZ during the LM as seen through oxygen isotopes in our proxy network, consistent with results presented by Campos et al. (2019) (Figs. 4c-d). The present-day footprint of SACZ variability is represented by correlations of both the OLR field and precipitation derived from station data with PC1 of the OLR EOF decomposition over the SACZ region. Loadings of opposite sign are seen in the core SACZ region and the subsidence region to the southwest in the proxy-derived mode as well as the present-day analysis. The only difference emerges over the Peruvian Andes where the MCEOF2 loadings are weak, yet the precipitation data projects negatively onto the present-day SACZ mode.

The interpretation of MCEOF2 as isolating isotopic variability related to SACZ shifts is consistent with previous studies (Novello et al., 2018; Campos et al., 2019). While records located close to the node of the dipole (SBE3+SMT5, TM0) have shown little variation over the LM (Wortham et al., 2017; Novello et al., 2018), records located to the southwest (CR1, ALHO6, Boto) are anticorrelated to those records in the northeast (MV, DV2), i.e. central-eastern Brazilian records are becoming more depleted (enriched) as southwestern records become more enriched (depleted) in heavy isotopes (Novello et al., 2018). The similarity between the correlation of leading EOF of OLR variability over the SACZ domain with local station precipitation and the isotope-derived MCEOF pattern strongly supports existing evidence of a precipitation amount effect driving isotopic variability in this region (Moquet et al., 2016; Novello et al., 2018). High moisture flux into this region during enhanced SACZ activity leads to the local decrease of $\delta^{18} \mathrm{O}$ anomalies recorded in proxy archives. Convective activity in the SACZ domain is fueled by moisture transported from the SALLJ and anticyclonic low-level flow originating over the tropical South Atlantic, converging with cold fronts entrained in the sub-tropical westerly jet. A more southerly SACZ location reflects a more north-south oriented SALLJ, invigorating convection along the foothills of the eastern Bolivian Andes and could explain why the Boto record projects so strongly onto this mode. At the same time, the southern location of the SACZ also results in stronger interaction with extratropical Rossby waves emanating north from the westerly jet (Kodama, 1992).

SACZ activity within the dipole structure suggested by MCEOF2, and underscored by the precipitation dependence 395 on OLR, is a function of the SAMS strength. Neilsen et al. (2019) document that the northernmost position of the SACZ is coincident with the onset and demise of the SAMS, while a more southern position is consistent with the peak phase of the SAMS. Though these results represent an intraseasonal perspective, the dynamics are consistent with an enhanced monsoon corresponding to the peak phase of monsoon activity. Hence, a strengthened monsoon is accompanied by a shift of the SACZ to the southwest and a decrease of rainfall along the northeastern SACZ margin, accompanied by the consequent 
https://doi.org/10.5194/cp-2022-6

Preprint. Discussion started: 31 January 2022

(c) Author(s) 2022. CC BY 4.0 License.

(c) (i)

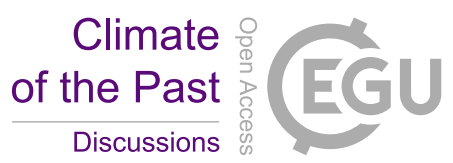

depletion of isotopic values co-located with shifts in convection (Novello et al., 2018). The regional loading pattern in MCEOF2 is indicative of a southwestern shift of the SACZ during in the LIA rather than a widening of the convective zone as has been previously suggested (Campos et al., 2019). This interpretation agrees with the dominant view in the literature that during the LIA, intensification of the SAMS was accompanied by reduced (enhanced) precipitation along the northeastern (southwestern) edge of the SACZ (Novello et al., 2012, 2018; Deininger et al., 2017). Coincident with an intensification of the SAMS core driving the SACZ to higher latitudes, this displacement has been shown on seasonal timescales to be linked to reduced SACZ convective intensity (Barros et al., 2000). This dynamic mechanism may reduce the magnitude of amount-effect driven $\delta^{18} \mathrm{O}$ distillation measured in proxies found in southeastern Brazil.

Though MCEOF2 is orthogonal to MCEOF1, the dominant shift in the mean state of PC2 and a similar shift in PC1 during the LIA period reflect a departure toward decreasing values of $\delta^{18} \mathrm{O}$. This was therefore a period when the SAMS was enhanced overall and both the ITCZ and the SACZ were displaced to the south of their mean locations. While the monsoon core loadings are positively correlated with PC1, central-eastern Brazil proxy loadings (MV, SBE3+SMT5, TM0, DV2) in the northern center of the SACZ dipole are negatively correlated with PC2, and thus during the LIA become relatively enriched in heavy isotopes compared to their mean state. The change in isotopic composition captured by proxies along the northeastern edge of the SACZ indicates a reduction in the local rainfall. The opposite is exhibited by the proxy loadings to the southwest, which are positively correlated with PC2.

In addition to being physically linked to Amazonian convection and moisture transport by the SALLJ, SACZ displacements have also been shown to be modulated by a variety of other external changes on different timescales. Changes in the SST of the South Atlantic Subtropical Dipole have influenced rainfall in northeastern Brazil and southeastern South America on millennial timescales in the past (Wainer et al., 2014) and also on intraseasonal timescales in the present-day climate (Chaves and Nobre, 2004). Other drivers of SACZ variability are linked to changes in anti-cyclonic flow associated with latitudinal shifts of the SASA (Zilli et al., 2019), increases in baroclinicity driven by subtropical incursions of transient synoptic systems from higher latitudes enhancing frontal activity in the region (Kodama, 1992; Novello et al., 2018), and propagating southern hemisphere Rossby wave trains (Gelbrecht et al., 2018).

\subsection{Model-derived MCEOF discussion}

\subsubsection{Model-EOF mode 1}

The leading EOFs derived from the isotope-enabled GCMs show remarkable consistency with those extracted from the proxy network, lending confidence to the use of the current generation of climate models in analyzing the dynamics giving rise to these spatial patterns of isotopic variability. There are, however, some discrepancies between the leading proxy- and model-based modes, especially for records located along the margin of the SAMS domain (PAR, Boto). Those records are more sensitive to large-scale circulation changes and related non-monsoonal influences outside the mature monsoon season (DJF). The PAR record, at the northern margin of the SAMS, currently receives $<40 \%$ of its annual rainfall 
https://doi.org/10.5194/cp-2022-6

Preprint. Discussion started: 31 January 2022

(c) Author(s) 2022. CC BY 4.0 License.

(c) (i)

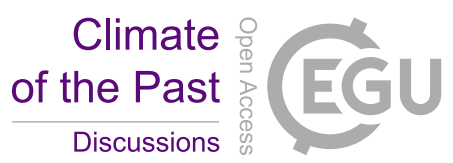

in DJF and is influenced by convective precipitation in the monsoon onset and demise phases prior to and after the DJF season. Furthermore, this site may also be influenced by past displacements in the convective margin that characterizes the boundary between Amazonian convection and NE Brazil subsidence in EOF 1 (Wang et al., 2017). The loadings of the Boto record, located on the eastern slopes of the Bolivian Andes along the exit region of the SALLJ, also show some discrepancies with the model simulations. Even though this location today receives precipitation almost exclusively during the peak monsoon season, it is located at a distal site of the SAMS. Small changes in the meridional extent of large- and meso-scale circulation systems, such as extratropical cold air incursions propagating north along the eastern Andes, have the potential to drastically change moisture source contributions and the isotopic signal (Apaéstegui et al., 2018). Such changes, especially in a region of complex topography, are difficult to resolve in a GCM and may explain some of the differences observed between the proxy and model EOF loadings in this region.

\subsubsection{Model-EOF mode 2}

The second model-derived mode represents SACZ variability, consistent with the findings of the proxy-based MCEOF2. The model results present a large loading center, while the proxy-based MCEOF2 displays some indication of a NE-SW dipole. The NE-SW shift of SACZ activity seen in MCEOF2 is driven by periods of weaker/stronger SAMS activity. Though the SACZ is an intrinsic component of the monsoon system, its behavior will vary in response to both external forcings and regional internal variability that modify the background climate. The lack of this dipole activity in the model-based EOF2 may point toward an inability of the models to correctly simulate the transient behavior of the SACZ, although iCESM appears to correctly simulate the southward displacement of the SACZ during the LIA (see section 4.3).

The temporal characteristics represented in the proxy PC time series (Figs. 2b-d) are not well replicated in the model-based EOF analysis (not shown). The models, particularly iCESM, exhibit principal component time series that are dominated by high-frequency variability around a stationary mean state, but lack power at lower frequencies documented in the proxy data. The proxy network-derived PCs indicate robust changes in the mean state, persisting for decades or centuries, but the models poorly reproduce the observed amplitude or persistence of the monsoon response to internal variability or external forcing. This suggests missing or misrepresented feedbacks within the climate models which are key to this sustained transient monsoon response. While diagnosing this performance is beyond the scope of the analysis presented herein, they are consistent with similar conclusions derived in previous analyses of the simulated SAMS response to external forcing during the LM (e.g., Rojas et al., 2016).

\subsection{MCA/LIA changes}

To further illustrate the application of isotope-enabled climate models for diagnosing past climate dynamics, we analyze spatial anomalies of three diagnostic variables during the MCA and LIA periods relative to the full LM. The centennial-scale departures from the mean state during these periods are observed in both individual records across the monsoon basin and extracted from the network by means of the MCEOF analysis as well as documented in the CESM LM 
https://doi.org/10.5194/cp-2022-6

Preprint. Discussion started: 31 January 2022

(c) Author(s) 2022. CC BY 4.0 License.

ensemble experiments (Otto-Bliesner et al., 2016). Here we employ model diagnostics from the iLME full-forcing

simulation ensemble average $(n=3)$ to examine dynamical changes associated with hydroclimatic perturbations observed during these time periods. During the MCA, upward motion in the mid-troposphere (500 hPa) is reduced over the tropical Andes, Peruvian Amazon, central Brazil, and in the monsoon trough region (South Atlantic Convergence Zone) (Fig. 5a). Anomalies during the LIA are roughly opposite, with enhanced vertical motion over the Amazon basin and central Brazil and increased rising motion along the southwestern margin of the South Atlantic Convergence Zone (Fig. 5b). These results support the hypothesis of a southwesterly SACZ shift during the LIA (Novello et al., 2018) rather than a stationary enhancement of convective activity.
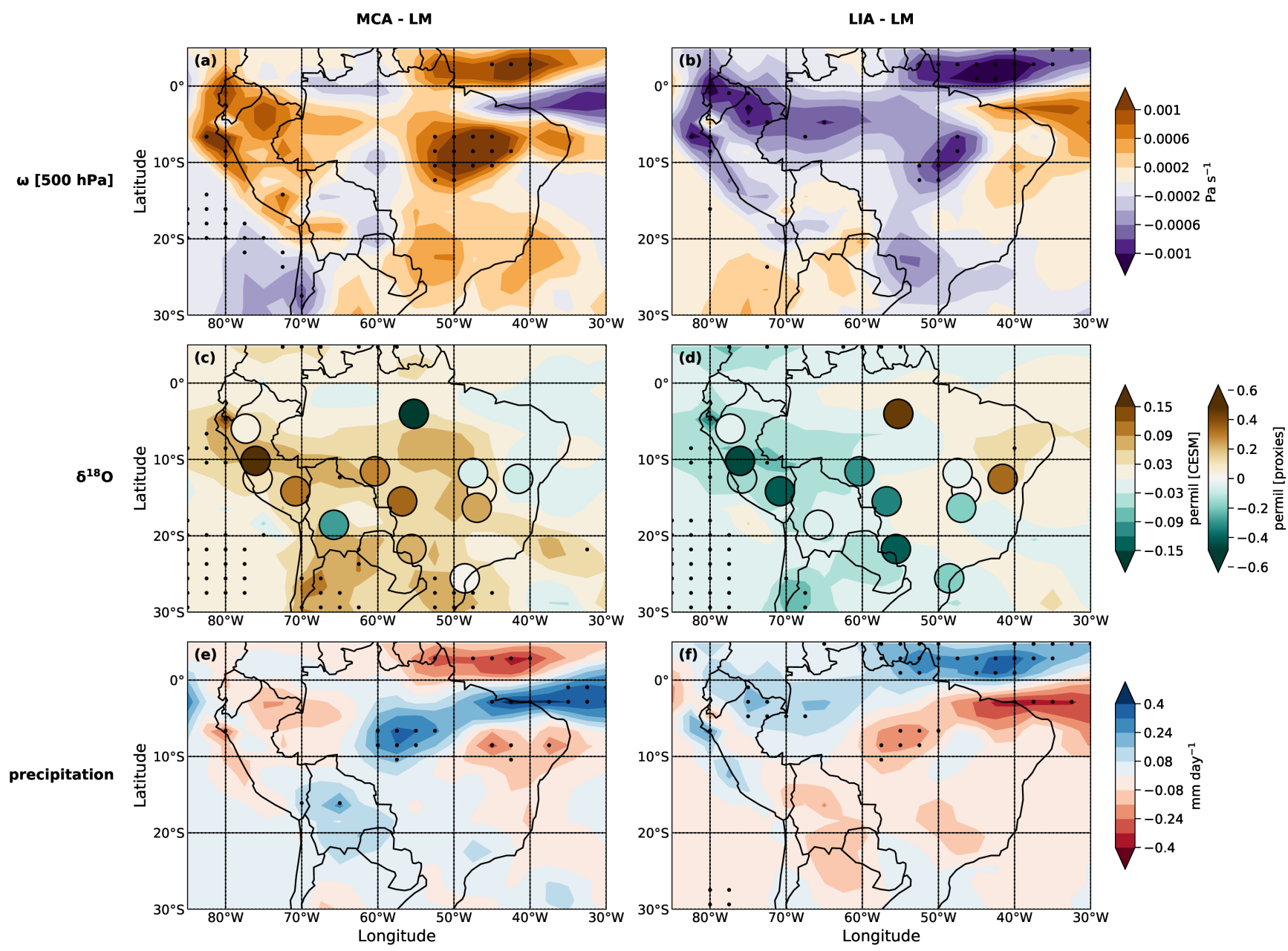

Figure 5: iCESM full-forcing multi-model mean anomalies during MCA (850-1160 CE; left column) and LIA (1489-1850 CE; right column) relative to the full LM (850-1850 CE) mean in austral summer (DJF) for a-b) mid-tropospheric vertical velocity $(500 \mathrm{hPa}, \mathrm{Pa} / \mathrm{s}$, note that negative anomalies signify enhanced upward motion / reduced subsidence), $\mathrm{c}-\mathrm{d})$ precipitation-weighted $\delta^{18} \mathrm{O}$ (permil; colored circles represent values from proxy MC 1000-member ensemble mean; note that color scales differ between proxy and model estimates) and e-f) precipitation ( $\mathrm{mm} /$ day). Stippling indicates regions where anomalies are significant at $p \leq 0.1$. 
Isotopic changes during the MCA and LIA are simulated surprisingly well in iCESM as far as the observed spatial pattern across SA are concerned (Figs. 5c-d), although the amplitude of the anomalies is lower in iCESM compared to the paleorecord (circles overlaid on the model-simulated contours). The MCA was a period of overall positive $\delta^{18} \mathrm{O}$ anomalies as seen in both the model and paleorecords, especially over the western Amazon, Andes, and downstream monsoon records. The Boto record stands out as a regional anomaly characterized by more negative values during the MCA (Fig. 5c). As discussed above, the isotopic signal at this distal site provides a challenge for the model to capture correctly, highlighting the value of increased observational studies to better understand regional variability in isotopic composition. The LIA period on the other hand shows a clear east-west dipole of $\delta^{18} \mathrm{O}$ anomalies in both the proxies and model (Fig. 5d), reminiscent of EOF1 and consistent with the large departure in PC1 during this time. Strong isotopic enrichment of heavy isotopes is observed over northeastern Brazil and associated with enhanced subsidence and reduced precipitation. Negative isotopic anomalies over the Andes are associated with enhanced upstream convection and high rainfall rates, while depleted isotopic anomalies in the downstream monsoon region are associated with enhanced local convection (Fig. 5b). Notably, precipitation anomalies during the MCA and LIA (Figs. 5e-f) are primarily located in the northern monsoon region and are coincident with changes in vertical motion but not $\delta^{18} \mathrm{O}$ changes. Instead, the isotopic signals are displaced downstream of the largest changes seen in vertical motion. This supports our interpretation of changes in oxygen isotopes in tropical precipitation being dominantly controlled by fractionation during rainout upstream and therefore integrating information associated with convective activity of the monsoon.

\section{Conclusions}

We employed a MCEOF decomposition to extract the main modes of hydroclimate variability that are shared across a network of oxygen isotope proxy records and separate them from local environmental factors that are unique to individual sites. The same decomposition was performed for isotope-enabled climate models that share the same modes as extracted from the oxygen isotope network. The two main modes of variability are interpreted in the context of SAMS dynamics over the LM, and are characterized by broad regional coherence across the proxy network. The physical underpinnings of the modes are explained by analogs that represent well-understood dynamic components of the present-day South American climate. This newly developed understanding of proxies as integrating regional dynamics promotes caution when interpreting individual records as representing changes in precipitation amount, which may be an oversimplification for regions of the monsoon where the model-based MCA/LIA analysis suggests strong upstream effects rather than local controls. The first mode of variability corresponds to an upper-tropospheric Rossby wave response to condensational heating over the Amazon basin during the mature phase of the monsoon, exciting or relaxing the BH-NL system. The enhancement (weakening) of the South American Monsoon during the LIA (MCA) is captured by the leading PC1 from the first MCEOF of the proxy records, resulting in modulation of the E-W precipitation dipole across the continent. While the spatial characteristics of this mode are quite accurately captured by climate models, they do not simulate the multi-centennial shifts 
https://doi.org/10.5194/cp-2022-6

Preprint. Discussion started: 31 January 2022

(c) Author(s) 2022. CC BY 4.0 License.

(c) (i)

in the mean state seen in the isotopic composition of the proxy records. The second mode of variability corresponds to changes in intensity and location of the monsoon convective axis (SACZ). The NE-SW shift in the SACZ captured by the MCEOF2 reaffirms the prevailing theory that the changes in monsoon strength are reflected by displacements in the mean SACZ position and intensity. While the model represents this mode as a single center of activity, it does correctly simulate a more southerly position of the SACZ during the LIA as compared to the MCA, consistent with proxy evidence (Novello et al., 2018). Nonetheless, the lack of low-frequency variations in the model-derived PCs suggests that a more detailed diagnosis of how feedback processes are represented at a regional scale in climate models will be important future work for improving model simulations of monsoonal and regional processes in models. Additionally, the generation of new highresolution paleorecords, particularly from the eastern slopes of the Andes along the trajectory of the SALLJ near Boto, would help to further document multi-centennial changes in South America and in the SACZ region over the LM.

Our results are in general agreement with earlier work by Campos et al. (2019), although here we show that the comparison of isotopic analyses with modern continental modes of precipitation as in Campos et al. (2019) is complicated by the fact that a multitude of factors besides precipitation govern isotopic variability across South America. The simplified interpretation of negative (positive) $\delta^{18} \mathrm{O}$ anomalies directly corresponding to enhanced (reduced) precipitation across the continent does not take into account the richness of the isotopic processes and atmospheric dynamics to which isotopic analysis can provide a wealth of insight.

It is also noteworthy that the main modes of variability do not appear to be linked to ENSO or Pacific SST forcing in general. ENSO leads to an in-phase precipitation and isotopic response between the tropical Andes and NE Brazil (drying and isotopic enrichment during the ENSO warm phase), while the response over SE Brazil is of the opposite phase (wetting and negative $\delta^{18} \mathrm{O}$ anomalies). This spatial response to ENSO is inconsistent with both MCEOF 1 and MCEOF 2. While the teleconnection mechanisms linking ENSO with tropical South American hydroclimate may not have been stationary throughout the LM, a more likely explanation involves the fact that the ENSO power spectrum resides mostly in the interannual band, which is not sufficiently resolved in our analysis. Here we focused instead on multi-decadal to centennialscale changes in the monsoon, such as occurred between the MCA and LIA. Hence our results do not imply that ENSO was irrelevant for tropical South American climate variability during the LM, but suggest instead that mean state changes in ENSO were not the dominant driver of centennial-scale monsoon changes in the LM.

By reconstructing the variability of these modes through the LM, we have established a baseline envelope of variability against which future change can be compared. The shared presence and spatial characteristics of these modes of isotopic variability in paleorecords and isotope-enabled climate models (both full-forcing and single-forcing experiments) affirms that their existence is intrinsic to the SAMS itself and results from stable boundary conditions such as the shape and latitudinal extent of the continent, Andean orography in particular, rather than as a consequence of external forcings.

Notwithstanding the spatial stability of these modes, their temporal evolution is characterized by clear multidecadal to centennial-scale departures from the mean state. The monsoon is shown to be responsive to external forcings and internal variability, though partitioning the attribution of low-frequency variability between particular drivers as not been 
https://doi.org/10.5194/cp-2022-6

Preprint. Discussion started: 31 January 2022

(c) Author(s) 2022. CC BY 4.0 License.

(c) (1)

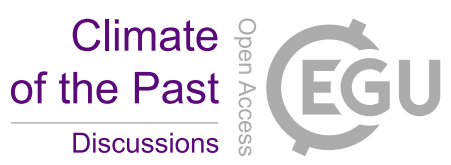

parsed out. While the low-frequency regional response to internal or external forcing is evident in the paleoclimate records, it is notably absent in model simulations. More detailed diagnosis of how feedback processes are represented at a regional

545 scale in climate models will therefore be important future work for improving model simulations of monsoonal and regional processes in models.

\section{Code and data availability}

Oxygen isotope samples used in this analysis are available from the National Centers for Environmental Information (NCEI) Paleo Data server (https://www.ncdc.noaa.gov/paleo/) and the University of São Paolo Geosciences speleothem database. 550 GPCP Precipitation data were obtained from NOAA NCEI at https://www.ncdc.noaa.gov/ghcn-daily-description. NOAA OLR and ERSST_V3b data are available from the NOAA/OAR/ESRL PSL, Boulder, Colorado, USA, from their website at https://psl.noaa.gov/. Python code to reproduce the analysis and figures are available through the open repository Zenodo (Orrison, 2022; https://zenodo.org/deposit/5889393).

\section{Author Contribution}

555 RO, MV, and JS designed the research plan. RO conducted the analysis, developed the figures, and wrote the manuscript draft. RO, MV, JS, JA, JLPSC, FWC, and MEDL contributed to reviewing and editing the final manuscript.

\section{Competing Interests}

The authors declare that they have no conflict of interest.

\section{Disclaimer}

560 Publisher's note: Copernicus Publications remains neutral with regard to jurisdictional claims in published maps and institutional affiliations.

\section{Acknowledgments}

We are grateful for the work of our collaborators in South America who collected and generated the network of proxy records, as well as for many helpful discussions regarding these proxy records. We thank A. LeGrande and D. Litchmore

565 who provided access to data from the GISS-E2-R LM simulations. Precipitation station data were provided by R. SerranoNotivoli within the framework of the project CAS/1900020 funded by the Spanish Ministry of Science and the Fulbright 
https://doi.org/10.5194/cp-2022-6

Preprint. Discussion started: 31 January 2022

(c) Author(s) 2022. CC BY 4.0 License.

(c) (i)

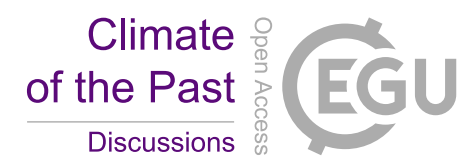

Foundation. Thanks also to K. Anchukaitis and G. Falster for discussions regarding the implementation of the MCEOF methodology.

570 This work is a contribution to the National Science Foundation funded Partnership for International Research and Education - Climate Research and Education in the Americas using Tree-ring and cave sediment Examples (PIRE-CREATE), a joint collaboration of the Department of Atmospheric and Environmental Sciences (DAES), SUNY-Albany, Albany, New York, USA, the Argentina Institute for Snow, Glacier and Environmental Research (IANIGLA), Mendoza, Argentina, the Institute of Geosciences, University of São Paulo (USP), São Paulo, Brazil, and the Lamont Doherty Earth Observatory (LDEO), Columbia University, Palisades, NY, USA. More information can be found at https://www.pirecreate.com/.

\section{Financial Support}

RO, MV and JS were partially supported by the National Science Foundation - Partnerships for International Research and Education (NSF-PIRE OISE-1743738). MV was partially supported by NSF-P2C2 (AGS-1702439 and EAR-2103041). JS was partially supported by NSF AGS-1602581, AGS-1805490 and AGS-2101214. JA was partially supported by PROCIENCIA through contract $\mathrm{N}^{\circ} 124-2020-F O N D E C Y T$. FWC, JLC and MDL were supported by the FAPESP-Brazil PIRE project (grant 2017/50085-3).

\section{References}

Ampuero, A., Stríkis, N. M., Apaéstegui, J., Vuille, M., Novello, V. F., Espinoza, J. C., Cruz, F. W., Vonhof, H., Mayta, V. C., Martins, V. T. S., Corderio, R. C., Azevedo, V. and Sifeddine, A.: The forest effects on the isotopic composition of 585 rainfall in the northwestern Amazon Basin., J. Geophys. Res.-Atmos., 125, doi: 10.1029/2019JD031445, 2020.

Anchukaitis, K. J. and Tierney, J. E.: Identifying coherent spatiotemporal modes in time-uncertain proxy paleoclimate records, Clim. Dynam., 41, 1291-1306, doi:10.1007/s00382-012-1483-0, 2013.

Apaéstegui, J., Cruz, F. W., Siffedine, A., Vuille, M., Espinoza, J. C., Guyot, J. L., Khodri, M., Strikis, N. M., Santos, R. V., Cheng, H., Edwards, R. L., Carvalho, E. and Santini, W.: Hydroclimate variability of the northwestern Amazon Basin near the Andean foothills of Peru related to the South American Monsoon System during the last 1600 years, Clim. Past, 10, 1967-1981, doi: 10.5194/cp-10-1967-2014, 2014. 
https://doi.org/10.5194/cp-2022-6

Preprint. Discussion started: 31 January 2022

(c) Author(s) 2022. CC BY 4.0 License.

(c) (i)

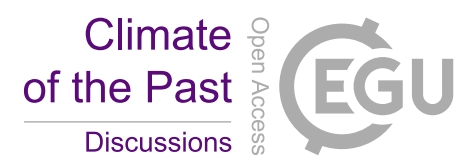

595 Apaéstegui, J., Cruz, F. W., Vuille, M., Fohlmeister, J., Espinoza, J. C., Siffedine, A., Strikis, N. M., Guyot, J. L., Ventura, R., Cheng, H. and Edwards, R. L.: Precipitation changes over the eastern Bolivian Andes inferred from speleothem $\left(\delta^{18} \mathrm{O}\right)$ records for the last 1400 years, Earth Planet. Sc. Lett., 494, 124-134, doi: 10.1016/j.epsl.2018.04.048, 2018.

Atwood, A. R., Battisti, D. S., Wu, E., Frierson, D. M. W. and Sachs, J. P.: Data-Model Comparisons of Tropical 600 Hydroclimate Changes Over the Common Era, Paleoceanogr. Paleocl., 36, doi: 10.1029/2020PA003934, 2021.

Azevedo, V., Stríkis, N. M., Santos, R. A., de Souza, J. G., Ampuero, A., Cruz, F. W., de Oliveira, P., Iriarte, J., Stumpf, C. F., Vuille, M., Mendes, V. R., Cheng, H. and Edwards, R. L.: Medieval Climate Variability in the eastern Amazon-Cerrado regions and its archeological implications, Sci. Rep., 9, 1-10, doi: 10.1038/s41598-019-56852-7, 2019.

605

Baker, J. C., Hunt, S. F., Clerici, S. J., Newton, R. J., Bottrell, S. H., Len, M. J., Heaton, T. H. E., Helle, G., Gloor, J. A. M. and Brienen, R. J. W.: Oxygen isotopes in tree rings show good coherence between species and sites in Bolivia, Global Planet. Change, 133, 298-308, doi: 10.1016/j.gloplacha.2015.09.008, 2015.

610 Barros, V. Y., Gonzalez, M., Liebmann, B. and Camilloni, I. Y.: Influence of the South Atlantic convergence zone and South Atlantic Sea surface temperature on interannual summer rainfall variability in Southeastern South America, Theor. Appl. Climatol., 133, 123-133, doi: 10.1007/s007040070002, 2000.

Berner, J., Achatz, U., Batté, L., Bengtsson, L., de la Cámara, A., Christensen, H. M., Colangeli, M., Coleman, D. R. B., 615 Crommelin, D., Dolaptchiev, S. I., Franzke, C. L. E., Friederichs, P., Imkeller, P., Järvinen, H., Juricke, S., Kitsios, V., Lott, F., Lucarini, V., Mahajan, S., Palmer, T. N., Penland, C., Sakradzija, M., von Storch, J.-S., Weisheimer, A., Weniger, M., Williams, P. D. and Yano, J.-I, Stochastic Parameterization: Toward a New View of Weather and Climate Models, B. Am. Meteorol. Soc., 98, 565-588, doi: 10.1175/BAMS-D-15-00268.1, 2017.

Bird, B. W., Abbott, M. B., Vuille, M., Rodbell, D. T., Stansell, N. D. and Rosenmeier, M. F.: A 2,300-year-long annually resolved record of the South American summer monsoon from the Peruvian Andes, P. Natl. Acad. Sci. USA, 108, 85838588, doi: 10.1073/pnas.1003719108, 2011.

Blake, S. A. P., Lewis, S. C., LeGrande, A. N. and Miller, R. L.: Assessing the impact of large volcanic eruptions of the last millennium (850-1850 CE) on Australian rainfall regimes, Clim. Past, 14, 811-824, doi: 10.5194/cp-14-811-2018, 2018. 
https://doi.org/10.5194/cp-2022-6

Preprint. Discussion started: 31 January 2022

(c) Author(s) 2022. CC BY 4.0 License.

(c) (i)

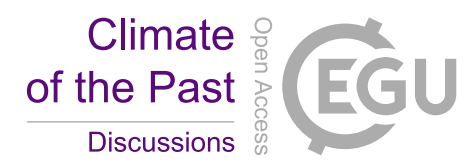

Brady, E., Stevenson, S., Bailey, D., Liu, Z., Noone, D., Nusbaumer, J., Otto-Bliesner, B. L., Tabor, C., Tomas, R., Wong, T., Zhang, J. and Zhu, J.: The Connected Isotopic Water Cycle in the Community Earth System Model Version 1, J. Adv. Model. Earth Sy., 11, 2547-2566, doi: 10.1029/2019MS001663, 2019.

630

Cai, W., McPhaden, M., Grimm, A., Rodrigues, R., Taschetto, A., Garreaud, R., Dewitte, B., Poveda, G., Ham, Y.-G., Santoso, A., Ng, B., Anderson, W., Wang, G., Geng, T., Jo, H.-S., Marengo, J., Alves, L., Osman, M., Li, S., Vera, C.: Climate impacts of the El Niño-Southern Oscillation on South America, Nat. Rev. Earth Environ., 1, 215-231, doi: 10.1038/ s43017-020-0040-3, 2020.

635

Campos, J. L. P. S., Cruz, F. W., Ambrizzi, T., Deininger, M., Vuille, M., Novello, V. F. and Strikis, N. M.: Coherent South American Monsoon Variability During the Last Millennium Revealed Through High-Resolution Proxy Records, Geophys. Res. Lett., 46, 8261-8270, doi: 10.1029/2019GL082513, 2019.

640 Carvalho, L. M. V., Jones, C. and Liebmann, B.: The South Atlantic Convergence Zone: Intensity, Form, Persistence, and Relationship with Intraseasonal to Interannual Activity and Extreme Rainfall, J. Climate, 17, 88-108, doi: 10.1175/15200442(2004)017<0088:TSACZI>2.0.CO;2, 2004.

Chaves, R. R. and Nobre, P.: Interactions between sea surface temperature over the South Atlantic Ocean and the South

Atlantic Convergence Zone, Geophys. Res. Lett., 31, L03204, doi: 10.1029/2003GL018647, 2004.

Chen, T. C., Weng, S. P. and Schubert, S.: Maintenance of Austral Summertime Upper-Tropospheric Circulation over Tropical South America: The Bolivian High-Nordeste Low System, J. Atmos. Sci., 56, 2081-2100, doi: 10.1175/15200469(1999)056<2081:MOASUT>2.0.CO;2, 1999.

650

Cheng, H., Sihna, A., Cruz, F. W., Wang, X., Edwards, R. L., d’Horta, F. M., Ribas, C. C., Vuille, M., Stott, L. D. and Auler, A. S.: Climate change patterns in Amazonia and biodiversity, Nat. Commun., 4: 41411, doi: 10.1038/ncomms2415, 2013.

Colose, C. M., LeGrande, A. N. and Vuille, M.: The influence of volcanic eruptions on the climate of tropical South America 655 during the last millennium in an isotope-enabled general circulation model, Clim. Past, 12, 961-979, doi: 10.5194/cp-12-9612016, 2016a.

Colose, C. M., LeGrande, A. N. and Vuille, M.: Hemispherically asymmetric volcanic forcing of tropical hydroclimate during the last millennium, Earth. Syst. Dyn., 7, 681-696, doi: 10.5194/esd-7-681-2016, 2016b. 
https://doi.org/10.5194/cp-2022-6

Preprint. Discussion started: 31 January 2022

(c) Author(s) 2022. CC BY 4.0 License.

(c) (1)

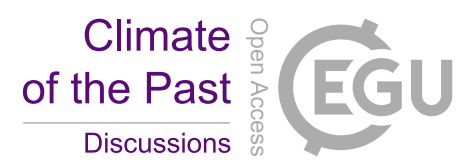

Cruz, F. W., Burns, S. J., Karmann, I., Sharp, W. D., Vuille, M., Cardoso, A. O., Ferrari, J. A., Silva Dias, P. L. and Viana, O.: Insolation-driven changes in atmospheric circulation over the past 116,000 years in subtropical Brazil, Nature, 434, 6366, doi: 10.1038/nature03365, 2005.

665 Cruz, F. W., Vuille, M., Burns, S. J., Wang, X., Cheng, H., Werner, M., Lawrence Edwards, R., Karmann, I., Auler, A. S. and Nguyen, H.: Orbitally driven east-west antiphasing of South American precipitation, Nat. Geosci., 2, 210-214, doi: 10.1038/ngeo444, 2009.

Dansgaard, W.: Stable isotopes in precipitation, Tellus, 16, 436-468, doi: 10.1134/1.1261687, 1964.

670

Deininger, M., McDermott, F., Mudelsee, M., Werner, M., Frank, N. and Mangini, A.: Coherency of late Holocene European speleothem $\delta^{18} \mathrm{O}$ records linked to North Atlantic Ocean circulation, Clim. Dynam., 49, 595-618, doi: 10.1007/s00382-016-3360-8, 2017.

675 Della Libera, M.E., V.F. Novello, F.W. Cruz, R. Orrison, M. Vuille, S.Y. Maezumi, J. de Souza, J.C. Rodriguez, J.L.P.S. Campos, A. Ampuero, G. Utida, N.M. Strikis, C. Fernandes Stumpf, V. Azevedo, H. Zhang, R.L. Edwards and H. Cheng: Paleoclimatic and paleoenvironmental changes in Amazonian lowlands over the last three millennia and their implications for pre-Columbian populations, Quaternary Sci. Rev., 2022.

680 Falster, G., Tyler, J., Grant, K., Tibby, J., Turney, C., Löhr, S., Jacobsen, G. and Kershaw, A. P.: Millennial-scale variability in south-east Australian hydroclimate between 30,000 and 10,000 years ago, Quaternary Sci. Rev., 192, 106-122, doi: 10.1016/j.quascirev.2018.05.031, 2018.

Fohlmeister, J., Voarintsoa, N. R. G., Lechleitner, F. A., Boyd, M., Brandtstätter, S., Jacobson, M. J. and Oster, J.: Main controls on the stable carbon isotope composition of speleothems, Geochim. Cosmochim. Ac., 279, 67- 87, doi: 10.1016/j.gca.2020.03.042, 2020.

Garreaud, R. D., Vuille, M., Compagnucci, R. and Marengo, J.: Present-day South American climate, Palaeogeogr. Palaeoecol., 281, 180-195, doi: 10.1016/j.palaeo.2007.10.032, 2009.

Gelbrecht, M., Boers, N. and Kurths, J.: Phase coherence between precipitation in South America and Rossby waves, Sci. Adv., 4, eaau3191, doi: 10.1126/sciadv.aau3191, 2018. 
https://doi.org/10.5194/cp-2022-6

Preprint. Discussion started: 31 January 2022

(c) Author(s) 2022. CC BY 4.0 License.

\section{(c) (1)}

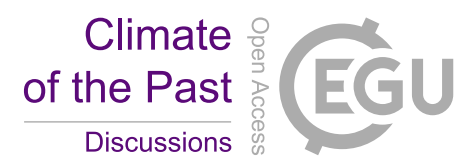

He, Z., Dai, A. and Vuille, M.: The joint impacts of Atlantic and Pacific multidecadal variability on South American precipitation and temperature, J. Climate, 34, 7959-7981, doi: 10.1175/JCLI-D-21-0081.1, 2021.

Hersbach, H., Bell, B., Berrisford, P., Hirahara, S., Horányi, A., Muñoz-Sabater, J., Nicolas, J., Peubey, C., Radu, R., Schepers, D. and Simmons, A.: The ERA5 global reanalysis, Q. J. Roy. Meteor. Soc., 146, 1999-2049, doi: https://doi.org/10.1002/qj.3803, 2020.

700

Kanner, L. C., Burns, S. J., Cheng, H., Edwards, R. L. and Vuille, M.: High-resolution variability of the South American summer monsoon over the last seven millennia: insights from a speleothem record from the central Peruvian Andes, Quaternary Sci. Rev., 75, 1-10, doi: 10.1016/j.quascirev.2013.05.008, 2013.

705 Kodama, Y.-M.: Large-scale common features of subtropical precipitation zones (The Baiu Frontal Zone, the SPCZ, and the SACZ) Part I: Characteristics of subtropical frontal zones, J. Meteorol. Soc. Jpn., 70, 813-836, doi: 10.2151/jmsj1965.70.4_813, 1992.

Kodama, Y.-M.: Large-Scale Common Features of Sub-Tropical Convergence Zones (The Baiu Frontal Zone, the SPCZ, and 710 the SACZ) Part II: Conditions of the Circulation for Generating STCZs, J. Meteorol. Soc. Jpn., 71, 581-610, doi: 10.2151/jmsj1965.71.5_581, 1993.

Konecky, B. L. Noone, D. C. and Cobb, K. M.: The Influence of Competing Hydroclimate Processes on Stable Isotope Ratios in Tropical Rainfall, Geophys. Res. Lett., 46, 1622-1633, doi: 10.1029/2018GL080188, 2019.

Lenters, J. D. and Cook, K. H: On the origin of the Bolivian high and related circulation features of the South American climate, J. Atmos. Sci., 54, 656-677, doi: 10.1175/1520-0469(1997)054<0656:otootb>2.0.co;2, 1997.

Liebmann, B. and Smith, C. A.: Description of a Complete (Interpolated) Outgoing Longwave Radiation Dataset, B. Am. Meteorol. Soc., 77, 1275-1277, 1996.

Mann, M. E., Rutherford, S., Wahl, E. and Ammann, C.: Robustness of proxy-based climate field reconstruction methods, J. Geophys. Res., 112, D12109, doi:10.1029/2006JD008272, 2007. Network-Daily Database, J. Atmos. Ocean. Tech., 29, 897-910, doi: 10.1175/JTECH-D-11-00103.1, 2012. 
https://doi.org/10.5194/cp-2022-6

Preprint. Discussion started: 31 January 2022

(c) Author(s) 2022. CC BY 4.0 License.

\section{(c) (i)}

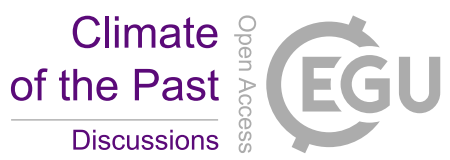

Moquet, J. S., Cruz, F. W., Novello, V. F., Strikis, N. M., Deininger, M., Karmann, I., Santos, R. V., Millo, C., Apaéstegui, J., Guyot, J. L., Siffedine, A., Vuille, M., Cheng, H., Edwards, R. L. and Santini, W.: Calibration of speleothem $\delta^{18} \mathrm{O}$ records against hydroclimate instrumental records in Central Brazil, Global Planet. Change, 139, 151-164, doi: 10.1016/j.gloplacha.2016.02.001, 2016.

Neilsen, D. M., Belém, A. L., Marton, E. and Cataldi, M.: Dynamics-based regression models for the South Atlantic Convergence Zone, Clim. Dynam., 52, 5527-5553, doi: 10.1007/s00382-018-4460-4, 2019.

North, G. R., Bell, T. L., Cahalan, R. F. and Moeng, F. J.: Sampling errors in the estimation of empirical orthogonal functions, Mon. Wea. Rev., 110, 699-706, doi:10.1175/1520-0493(1982)110<0699:SEITEO>2.0.CO;2, 1982.

Novello, V. F., Cruz, F. W., Karmann, I., Burns, S. J., Strikis, N. M., Vuille, M., Cheng, H., Lawrence Edwards, R., Santos, 740 R. V., Frigo, E. and Barreto, E. A. S.: Multidecadal climate variability in Brazil's Nordeste during the last 3000 years based on speleothem isotope records, Geophys. Res. Lett., 39, 1-6, doi: 10.1029/2012GL053936, 2012.

Novello, V. F., Cruz, F. W., Moquet, J. S., Vuille, M., de Paula, M. S., Nunes, D., Edwards, R. L., Cheng, H., Karmann, I., Utida, G., Stríkis, N. M. and Campos, J. L. P. S.: Two Millennia of South Atlantic Convergence Zone Variability 745 Reconstructed From Isotopic Proxies, Geophys. Res. Lett., 45, 5045-5051, doi: 10.1029/2017GL076838, 2018.

Novello, V. F., Cruz, F. W., Vuille, M., Campos, J. L. P. S., Strikis, N. M., Apaéstegui, J., Moquet, J. S., Azevedo, V., Ampuero, A., Utida, G., Wang, X., Paula-Santos, G. M., Jaqueto, P., Ruiz Pessenda, L. C., Breeker., D. O. and Karmann, I.: Investigating $\delta^{13} \mathrm{C}$ values in stalagmites from tropical South America for the last two millennia, Quaternary Sci. Rev., 255, 106822, doi: 10.1016/j.quascirev.2021.106822, 2021.

Novello, V. F., Vuille, M., Cruz, F. W., Strikis, N. M., De Paula, M. S., Edwards, R. L., Cheng, H., Karmann, I., Jaqueto, P. F., Trindade, R. I. F., Hartmann, G. A. and Moquet, J. S.: Centennial-scale solar forcing of the South American Monsoon System recorded in stalagmites, Sci. Rep., 6, 1-8, doi: 10.1038/srep24762, 2016.

Orrison, R., SAMS MCEOF, Zenodo [software], https://zenodo.org/deposit/5889393, 2022

Otto-Bliesner, B. L., Brady, E. C., Fasullo, J., Jahn, A., Landrum, L., Stevenson, S., Rosenbloom, N., Mai, A. and Strand, G.: Climate Variability and Change since 850 CE: An Ensemble Approach with the Community Earth System Model, B. Am. Meteorol. Soc., 97, 735-754, doi: 10.1175/bams-d-14-00233.1, 2016. 
https://doi.org/10.5194/cp-2022-6

Preprint. Discussion started: 31 January 2022

(c) Author(s) 2022. CC BY 4.0 License.

\section{(c) (1)}

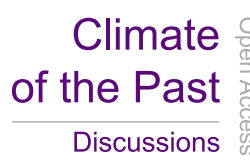

Risi, C. and Bony, S.: Influence of convective processes on the isotopic composition $\left(\delta^{18} \mathrm{O}\right.$ and $\left.\delta \mathrm{D}\right)$ of precipitation and water vapor in the tropics: 2. Physical interpretation of the amount effect, J. Geophys. Res.-Atmos., 113, 1-12, doi: 10.1029/2008JD009943, 2008.

765

Rodriguez-Caton, M., L. Andreu-Hayles, V. Daux, M. Vuille, A. Varuolo-Clarke, R. Oelkers, D.A. Christie, R. D’Arrigo, M.S. Morales, M. Palat Rao, A.M. Srur, F. Vimeux and R. Villalba: Hydroclimate and ENSO variability recorded by oxygen isotopes from tree rings in the South American Altiplano. Geophys. Res. Lett., doi:10.1029/2021GL095883, 2022.

Rodwell, M. J. and Hoskins, B. J.: Subtropical anticyclones and summer monsoons, J. Climate, 14, 3192-3211, doi: 10.1175/1520-0442(2001)014<3192:SAASM>2.0.CO;2, 2001.

Rojas, M., Arias, P. A., Flores-Aqueveque, V., Seth, A. and Vuille, M.: The South American Monsoon variability over the last millennium in climate models, Clim. Past, 12, 1681-1691, doi: 10.5194/cp-12-1681-2016, 2016.

Salati, E., Dall’Olio, A., Matsui, E. and Gat, J.: Recycling of water in the Amazon Basin: An isotopic study, Water Resour. Res., 15, 1250-1258, doi: 10.1029/WR015i005p01250, 1979.

Schmidt, G. A., Jungclaus, J. H., Ammann, C. M., Bard, E., Braconnot, P., Crowley, T. J., Delaygue, G., Joos, F., Krivova,

N. A., Muscheler, R., Otto-Bliesner, B. L., Pongratz, J., Shindell, D. T., Solanki, S. K., Steinhilber, F. and Vieira, L. E. A.: Climate forcing reconstructions for use in PMIP simulations of the last millennium (v1.0), Geosci. Model Dev., 4, 33-45, doi: 10.5194/gmd-4-33-2011, 2011.

Schmidt, G. A., Kelley, M., Nazarenko, L., Ruedy, R., Russell, G. L., Aleinov, I., Bauer, M., Bauer, S., Bhat, M. K., Bleck,

R.,Canuto, V., Chen, Y., Cheng, Y., Clune, T. L., DelGenio, A., deFainchtein, R., Faluvegi, G., Hansen, J. E., Healy, R. J., Kiang, N. Y., Koch, D., Lacis, A. A., LeGrande, A. N., Lerner, J., Lo, K. K., Matthews, E. E., Menon, S., Miller, R. L., Oinas, V., Oloso, A., Perlwitz, J., Puma, M. J., Putman, W. M., Rind, D., Romanou, A., Sato, M., Shindell, D. T., Sun, S., Syed, R., Tausnev, N., Tsi-garidis, K., Unger, N., Voulgarakis, A., Yao, M.-S. and Zhang, J.: Configuration and assessment of the GISS ModelE2 contributions to the CMIP5 archive, J. Adv. Model. Earth Syst., 6, 141-184, doi: 10.1002/2013MS000265, 2014.

Schmidt, G. A., LeGrande, A. N. and Hoffmann, G.: Water isotope expressions of intrinsic and forced variability in a coupled ocean-atmosphere model, J. Geophys. Res. Atmos., 112, D10103, doi: 10.1029/2006JD00778, 2007. 
https://doi.org/10.5194/cp-2022-6

Preprint. Discussion started: 31 January 2022

(c) Author(s) 2022. CC BY 4.0 License.

(c) (i)

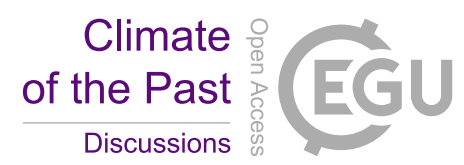

795 Smerdon, J. E.: Climate models as a test bed for climate reconstruction methods: pseudoproxy experiments, WIREs Clim. Change, 3, 63-77, doi: 10.1002/wcc.149, 2012.

Stevenson, S., Otto-Bliesner, B. L., Brady, E. C., Nusbaumer, J., Tabor, C., Tomas, R., Noone, D. C. and Liu, Z.: Volcanic Eruption Signatures in the Isotope-Enabled Last Millennium Ensemble, Paleoceanogr. Paleocl., 34, 1534- 1552, doi: 800 10.1029/2019PA003625, 2019.

Sturm, C., Vimeux, F. and Krinner, G.: Intraseasonal variability in South America recorded in stable water isotopes, J. Geophys. Res.-Atmos., 112, https://doi.org/10.1029/2006JD008298, 2007.

805 Sulca, J., Vuille, M., Silva, Y. and Takahashi, K.: Teleconnections between the Peruvian central Andes and Northeast Brazil during extreme rainfall events in austral summer, J. Hydrometeorol., 17, 499-515, doi: 10.1175/JHM-D-15-0034.1, 2016.

Sulca, J., Takahashi, K., Espinoza, J.-C., Vuille, M. and Lavado, W.: Impacts of different ENSO flavors and tropical Pacific convection variability (ITCZ, SPCZ) on austral summer rainfall in South America, with a focus on Peru, Int. J. Climatol., 38, 420-435, doi: 10.1002/joc.5185, 2018.

Thompson, L. G., Mosley-Thompson, E., Bolzan, J. F. and Koci, B. R.: A 1500 year record of climate variability recorded in ice cores from the tropical Quelccaya Ice Cap, Science, 229: 361-364, doi: 10.1126/science.229.4717.971, 1985.

815 Thompson, L. G., Mosley-Thompson, E., Davis, M. E., Zagorodnov, V. S., Howat, I. M., Mikhalenko, V. N. and Lin, P. N.: Annually resolved ice core records of tropical climate variability over the past 1800 years, Science, 340, 945-950, doi: 10.1126/science.1234210, 2013.

Tyler, J. J., Mills, K., Barr, C., Sniderman, J. M. K., Gell, P. A. and Karoly, D. J.: Identifying coherent patterns of 820 environmental change between multiple, multivariate records: an application to four 1000-year diatom records from Victoria, Australia, Quaternary Sci. Rev., 119, 94-105, doi: 10.1016/j.quascirev.2015.04.010, 2015.

Vera, C., Higgins, W., Amador, J., Ambrizzi, T., Garreaud, R., Gochis, D., Gutzler, D., Lettenmaier, D., Marengo, J., Mechoso, C. R., Nogues-Paegle, J., Silva Dias, P. L. and Zhang, C.: Toward a unified view of the American monsoon systems, J. Climate, 19, 4977-5000, doi: 10.1175/JCLI3896.1, 2006. 
https://doi.org/10.5194/cp-2022-6

Preprint. Discussion started: 31 January 2022

(c) Author(s) 2022. CC BY 4.0 License.

(c) (i)

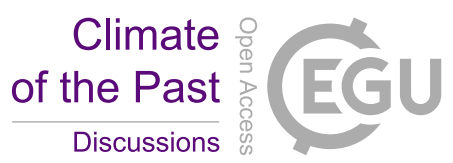

Vimeux, F., Ginot, P., Schwikowski, M., Vuille, M., Hoffman, G., Thompson, L. and Schotterer, U.: Climate variability during the last 1000 years inferred from Andean ice cores: A review of methodology and recent results, Palaeogeogr. Palaeocl., 281, 229-241, doi: 10.1016/j.palaeo.2008.03.054, 2009.

830

Vuille, M., Bradley, R. S., Werner, M., Healy, R. and Keimig, F.: Modeling $\delta^{18} \mathrm{O}$ in precipitation over the tropical Americas: 1. Interannual variability and climatic controls, J. Geophys. Res., 108, 4174, doi: 10.1029/2001jd002038, 2003.

Vuille, M., Burns, S. J., Taylor, B. L., Cruz, F. W., Bird, B. W., Abbott, M. B., Kanner, L. C., Cheng, H. and Novello, V F.: 835 A review of the South American monsoon history as recorded in stable isotopic proxies over the past two millennia, Clim. Past, 8, 1309-1321, doi: 10.5194/cp-8-1309-2012, 2012.

Vuille, M. and Werner, M.: Stable isotopes in precipitation recording South American summer monsoon and ENSO variability: Observations and model results, Clim. Dynam., 25, 401-413, doi: 10.1007/s00382-005-0049-9, 2005.

840

Wainer, I., Prado, L., Khodri, M. and Otto-Bliesner, B.: Reconstruction of the South Atlantic Subtropical Dipole index for the past 12,000 years from surface temperature proxy, Sci. Rep., 4, 1-8, doi: 10.1038/srep05291, 2014.

Wang, J., Emile-Geay, J., Guillot, D., Smerdon, J. E. and Rajaratnam, B., Evaluating climate field reconstruction techniques

using improved emulations of real-world conditions, Clim. Past, 10, 1-19, doi: 10.519194/cp-10-1-2014, 2014.

Wang, X., Edwards, R. L., Auler, A. S., Cheng, H., Kong, X., Wang, Y., Cruz, F. W., Dorale, J. A. and Chiang, H. W.: Hydroclimate changes across the Amazon lowlands over the past 45,000 years, Nature, 541, 204-207, doi: 10.1038/nature20787, 2017.

850

Wortham, B. E., Wong, C. I., Silva, L. C. R., McGee, D., Montañez, I. P., Troy Rasbury, E., Cooper, K. M., Sharp, W. D., Glessner, J. J. G. and Santos, R. V.: Assessing response of local moisture conditions in central Brazil to variability in regional monsoon intensity using speleothem ${ }^{87} \mathrm{Sr} /{ }^{86} \mathrm{Sr}$ values, Earth Planet. Sc. Lett., 463, 310-322, doi: 10.1016/j.epsl.2017.01.034, 2017.

855

Zhou, J. and Lau, K. M.: Does a monsoon climate exist over South America?, J. Climate, 11, 1020-1040, doi: 10.1175/15200442(1998)011<1020:DAMCEO>2.0.CO;2, 1998.

Zilli, M. T., Carvalho, L. M. V. and Lintner, B. R.: The poleward shift of South Atlantic Convergence Zone in recent decades, Clim. Dyn., 52, 2545-2563, doi: 10.1007/s00382-018-4277-1, 2019. 